\author{
UNIVERSIDADE DE SÃO PAULO \\ FACULDADE DE FILOSOFIA, LETRAS E CIÊNCIAS HUMANAS \\ DEPARTAMENTO DE FILOSOFIA \\ PROGRAMA DE PÓS-GRADUAÇÃO EM FILOSOFIA
}

Lucila Lang Patriani de Carvalho

Lévinas, Blanchot: O gênero da Filosofia

\title{
Exemplar corrigido
}

São Paulo

2019 


\section{Lucila Lang Patriani de Carvalho}

Lévinas, Blanchot: O gênero da Filosofia

Exemplar corrigido

Tese apresentada ao programa de PósGraduação em Filosofia do Departamento de Filosofia da Faculdade de Filosofia, Letras e Ciências Humanas da Universidade de São Paulo, para obtenção do título de Doutora em Filosofia sob a orientação do Prof. Dr. Franklin Leopoldo e Silva. 
Autorizo a reprodução e divulgação total ou parcial deste trabalho, por qualquer meio convencional ou eletrônico, para fins de estudo e pesquisa, desde que citada a fonte.

Catalogação na Publicação

Serviço de Biblioteca e Documentação

Faculdade de Filosofia, Letras e Ciências Humanas da Universidade de São Paulo

C331] Carvalho, Lucila Lang Patriani de Lévinas, Blanchot: o gênero da Filosofia / Lucila Lang Patriani de Carvalho ; orientador Franklin Leopoldo e Silva. - São Paulo, 2019. $100 \mathrm{f}$.

Tese (Doutorado)- Faculdade de Filosofia, Letras e Ciências Humanas da Universidade de São Paulo. Departamento de Filosofia. Área de concentração: Filosofia.

1. Blanchot. 2. Lévinas. 3. Filosofia. 4. Literatura. 5. Comunidade. I. Silva, Franklin Leopoldo e, orient. II. Título. 


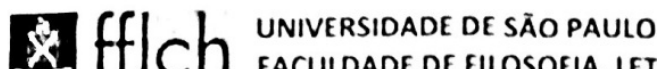

FACULDADE DE FILOSOFIA, LETRAS E CIÊNCIAS HUMANAS

\section{ENTREGA DO EXEMPLAR CORRIGIDO DA DISSERTACÃO/TESE}

Termo de Ciência e Concordância do (a) orientador (a)

Nome do (a) aluno (a):

Data da defesa:

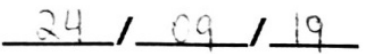

Nome do Prof. (a) orientador (a):

Franklin Leopidido e Sivo

Nos termos da legislação vigente, declaro ESTAR CIENTE do conteúdo deste EXEMPLAR CORRIGIDO elaborado em atenção às sugestões dos membros da comissão Julgadora na sessão de defesa do trabalho, manifestando-me plenamente favorável ao seu encaminhamento e publicação no Portal Digital de Teses da USP.

São Paulo, 03101 2080

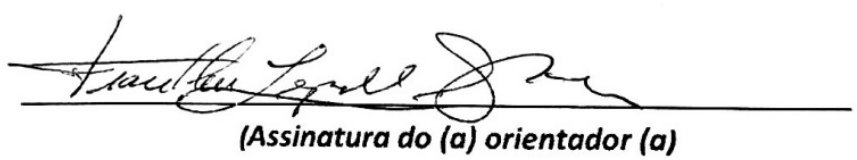


CARVALHO, L. L. P. Lévinas, Blanchot: O gênero da Filosofia. 2019. Tese (Doutorado) - Faculdade de Filosofia, Letras e Ciências Humanas. Departamento de Filosofia, Universidade de São Paulo, São Paulo, 2019.

Aprovado em: 24/09/2019

Prof. Dr. Franklin Leopoldo e Silva (USP) - Orientador

Prof. Dr. Eclair Antonio Almeida Filho (UnB),

Profa. Dra. Neide Coelho Boechat (UNIFAE)

Prof. Dr. Luiz Augusto Contador Borges (Externo) 
À minha mãe, Hilda Vasconcellos Lang. 


\section{Agradecimentos}

Ao professor Franklin Leopoldo e Silva pela orientação recebida desde a Iniciação Científica, por me ensinar o verdadeiro significado do que é ser professor e por tanta generosidade, sempre.

À minha mãe, Hilda Vasconcellos Lang, por me mostrar que tudo é uma questão de manter "a mente quieta, a espinha ereta e o coração tranquilo" e por me ensinar, em todo o seu companheirismo, que o amor a tudo compreende.

À Lívia Maria Nogueira Machado Fernandes de Melo, pelo companheirismo e paciência.

Aos meus avôs, Vilfredo Govea Lang (in memorian)e Oswaldo de Toledo (in memorian), às minhas avós, Elena Vasconcellos Lang e Helita Léa, À minha tia, Luiza Lang os maiores entusiastas de qualquer empreitada.

Ao Ricardo, à Mariana e ao meu pai, Carlos Eduardo Patriani de Carvalho, pelo apoio e pelos crescentes "diálogos filosóficos" em nossa convivência.

Ao Lourenço Fernandes, ao Lucas Nascimento, ao Sacha Kontic, ao Eduardo Marinho, à Julia Marchevsky, ao Jefferson Viel e à Ravena Olinda pelas conversas infindáveis que a tantos questionamentos levaram e outros esclareceram, pela amizade contruída para além dos corredores e que tornaram o percurso menos solitário. 
Aos meus alunos da Faculdade Sumaré e do Colégio João XXIII, por me ensinarem tanto em sala de aula.

À professora Dra. Claudia Consuelo Amigo Pino contador e ao Professor Dr. Luiz Augusto Contador Borges pelos preciosos apontamentos no exame de qualificação, determinantes para as diretrizes tomadas a partir de então.

À Secretaria do Departamento de Filosofia, por meio da Geni Ferreira Lima, Luciana Nóbrega, Marie Marcia Pedroso e Ruben Dario, pelo trabalho constante, pela paciência e boa vontade ao longo de tantos anos. 


\section{Resumo}

CARVALHO, L. L. P. Lévinas, Blanchot: O gênero da Filosofia. 2019. Tese (Doutorado) - Faculdade de Filosofia, Letras e Ciências Humanas. Departamento de Filosofia, Universidade de São Paulo, São Paulo, 2019.

Nosso trabalho possui, ainda que indiretamente, intenções plurais, sendo a mais evidente delas, abordar a relação intelectual estabelecida entre Emmanuel Lévinas e Maurice Blanchot. Tal relação possui, como subsídio para o seu desenvolvimento, os campos da filosofia e da literatura, que serão abordadas a partir da peculiar perspectivas de Blanchot. No mais, utilizamos o conceito de comunidade conforme pensado por Blanchot como eixo articulador de seu pensamento, que recebe destaque em relação a outros temas relevantes - prioritariamente o conceito de fora e de neutro, indispensáveis para a compreensão do pensamento blanchotiano - e possui uma concepção relacionada ao temas estudados por Lévinas.

Palavras-Chave: Blanchot, Lévinas, Filosofia, Literatura, Comunidade. 


\section{Abstract}

CARVALHO, L. L. P. Lévinas, Blanchot: The genre of Philosophy. 2019. Thesis (Doctorate Degree) - Faculdade de Filosofia, Letras e Ciências Humanas. Departamento de Filosofia, Universidade de São Paulo, São Paulo, 2019.

Our work has, although indirectly, plural intentions, being the most evident of them, to approach the intellectual relation established between Emmanuel Lévinas and Maurice Blanchot. This relationship has, as a subsidy for its development, the fields of philosophy and literature, which will be approached from the peculiar perspectives of Blanchot. Moreover, we use the concept of community as conceived by Blanchot as the articulating axis of his thought, which is highlighted in relation to other relevant themes - primarily the concept of outside and neutral, indispensable for understanding Blanchetian thinking - and has a conception related to the themes studied by Lévinas.

Keyords: Blanchot, Lévinas, Philosophy, Literature, Community 


\section{Sumário}

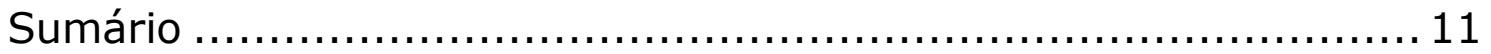

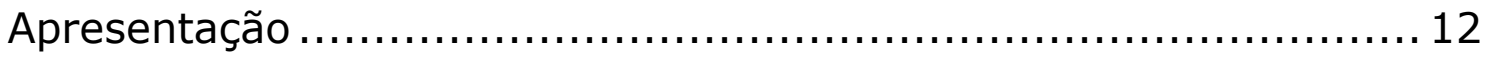

Capítulo 1 - Introdução: a situação da escrita de Blanchot ........... 14

1.1 - Literatura, Filosofia e a tradição francesa ........................ 15

1.2 - Interlocutores privilegiados .................................. 24

1.3 - As questões levantadas pela conjuntura história e política ... 28 Capítulo 02 - A escrita de Blanchot ou como escrever sobre Blanchot sem traí-lo............................................................ 32

2.1 - A presença de Blanchot no cenário francês contemporâneo . 33

2.2 - A fragmentação ............................................... 42

2.3 - Filosofia e Literatura em Blanchot.............................. 49

Capítulo 03 - A aproximação de Blanchot e Lévinas ..................... 60

3.1 - O entorno de Lévinas ........................................... 62

3.2 - Reconstrução dos pressupostos filosóficos ...................... 65

Capítulo 04 - A leitura blanchotiana de Lévinas .......................... 80

Considerações Finais ................................................... 90

Bibliografia ............................................................. 92 


\section{Apresentação}

Nosso trabalho se propõe, inicialmente, a articular a relação entre Filosofia e Literatura em Blanchot, priorizando o posicionamento de que há uma implicação necessária na construção de seu pensamento ambos os campos do saber e atentando ao modo como a existência, na filosofia Francesa Contemporânea não pode renunciar a ambas para se perfazer.

Assim, estabeleceremos um breve panorama da estrutura do pensamento de Blanchot, assim como a situação deste em meio ao cenário intelectual francês contemporâneo. Quanto a isto, cabe apontarmos que o pensamento de Blanchot se encontra em estado embrionário no Brasil, porém, em desenvolvimento crescente - com parte dos livros de Blanchot sendo traduzidos nas últimas décadas para o português, assim como o início de encontros e produções bibliográficas sobre o autor. Privilegiamos a bibliografia de Blanchot existente em português - embora ainda grande parte de suas obras não possuam tradução ainda e grande parte da bibliografia produzida por comentadores de Blanchot foi importada e com os trechos traduzidos para este trabalho.

Para subsidiarmos a proposta argumentativa acima explicitada há, ainda, uma segunda proposta de nosso trabalho, qual seja a de abordar o pensamento de Blanchot a partir de sua relação com Lévinas e contemplando, em certa medida, o próprio pensamento deste filósofo. Assim, será necessário um recorte temático preciso, de modo a contemplar aspectos do pensamento dos autores que estejam vinculados às concepções de Literatura e de Filosofia que se fazem aqui presentes. 
Para tanto, passaremos por alguns temas específicos dentro do pensamento de Lévinas - a exemplo do Infinito e da Linguagem - e que consideramos relevantes para a construção das concepções de Blanchot - em especial articulação entorno do conceito de Fora e de Neutro - conceitos cujas extensões serão delimitadas desde o primeiro momento da localização da situação do pensamento de Blanchot.

Ao analisarmos estas implicações do pensamento de Lévinas em temas centrais do pensamento de Blanchot, cabe destacarmos dede o início que não seria possível considerarmos, por exemplo, dois momentos diferentes para a intensidade da influência de Lévinas, uma vez que a relação entre ambos percorre o desenvolvimento do pensamento de Blanchot desde seu início.

Assim, intentamos apontar o modo como os conceitos centrais de Lévinas observados por Blanchot, que podemos aproximar à própria peculiaridade do pensamento de Lévinas ao apresentar a Ética como Filosofia Primeira no cenário da Filosofia Francesa Contemporânea e também, de certo modo, no atual cenário de análise da própria Filosofia Ocidental - que é levantada por Lévinas em "Totalidade e Infinito", mas que se faz presente anteriormente a exemplo das críticas de Heidegger ao anunciar o fim da Filosofia.

Tal percurso, aqui concretizado ao menos em parte, passaria, ainda que em parte e de modo indireto, pelo conceito de "comum" e de "comunidade" nos moldes concebidos por Blanchot e formado por ele e por Lévinas. 


\section{Capítulo 1 - Introdução: a situação da escrita de Blanchot}

A intenção presente neste capítulo é a de situar o pensamento do Maurice Blanchot em meio à produção intelectual francesa contemporânea.

Neste contexto, mais do que adequar 0 autor às nomenclaturas tradicionalmente utilizadas ou de classificar e estancar a escrita de Blanchot em um formato que segue parâmetros préestabelecidos por pensadores e por comentadores - a exemplo do que a proposta de um alinhamento de sua escrita ao estruturalismo ou ao pós-estruturalismo acarretaria -, o que intentamos é a de acentuar a presença de alguns temas no cenário do pensamento contemporâneo (no qual convergem as questões da literatura e da filosofia) que convergem na produção do pensamento de Blanchot.

Ao menos neste primeiro momento, antes de entrarmos especificamente na figura do autor e nas questões que tangenciam a composição da estrutura de escrita que Ihes são peculiares - que marcam uma certa reclusão e obscuridade -, já podemos adiantar que a presença e interação de Blanchot neste contexto intelectual nem sempre possibilita uma nítida comunicação do autor com outros pensadores, assim como a sua relação expressa com conceitos filosóficos e a assunção de determinados posicionamentos.

Para subsidiar esta contextualização cabe apontarmos que a parca literatura traduzida que detém sua análise neste período do pensamento francês pouco menciona Blanchot e, ao mesmo tempo, se debruça sobre a especificidade de seu pensamento, fazendo com que sua interação se sobressaia. Assim, o que se destaca é a 
ausência de menções à Blanchot, exceto na literatura especializada francesa, conforme melhor veremos adiante.

Deste modo, optamos por realizar o recorte a partir de duas frentes que são capazes de reconstruir o contexto que intentamos: uma mais ampla e geral, que possibilita, a grosso modo, destacar os temas presentes no pensamento contemporâneo francês que são relevantes para o recorte que aqui pretendemos - quais sejam, a filosofia e a literatura, já apontado anteriormente -, e outro mais restrito, proporcionado pela releitura de comentadores específicos de Blanchot - a exemplo de Leslie Hill, Françoise Collin, Michel Surya e Éric Hoppenot - mais bem concretizado no Capítulo seguinte a este mais abrangente.

\section{1 - Literatura, Filosofia e a tradição francesa}

A proposta de destacarmos um liame entre a Filosofia e a Literatura, de modo a estabelecermos um campo de análise que compreenda um panorama histórico encontra raízes remotas, retrocedendo até a Antiguidade grega. A parte de todas as questões inerentes aos pensadores e às conjunturas sociais e filosóficas de cada período, desde Platão em $A$ República ${ }^{1}$ a teoria da literatura ainda, naquela ocasião, por meio de uma análise da narrativa e da poética e ressalvadas todas as diferenças conceituais que 0

\footnotetext{
${ }^{1}$ A título de exemplo apenas, apontamos a seguinte passagem d'A República: "Entre os gêneros da poesia e da prosa, como dizes, um consiste inteiramente numa imitação, tragédia e comédia; o outro, num relato feito pelo próprio poeta que poderás encontrar principalmente nos ditirambos. Há ainda outro que, por meio dos dois recursos, ocorre na poesia épica e em outros textos. (PLATÃO, 2006, p. 99).
} 
deslocamento temporal e espacial da presente proposta comporta - é problematizada sob um ponto de vista filosófico - seja pela dramaticidade do diálogo, seja em razão do que a literatura representaria à sociedade.

Para Platão a literatura (expressa por meio da poesia), assim como as artes de modo geral, estariam afastadas, em três graus diferentes, da verdade em razão de sua própria estrutura de composição, pois esta seria meramente imitação e pautada pela aparência da representação. Tal situação é determinante para Platão rechace a poesia, não merecendo esta lugar na República que, justamente, almeja alcançar a verdade - o que é feita pela via da filosofia.

Neste contexto, é interessante remetermos nossa análise ao posicionamento de Aristóteles sobre o tema. Na Poética, Aristóteles afirma, por sua vez, que a imitação seria própria à natureza humana (ARISTÓTELES, 1987, p. 203). Tal consideração é responsável por inserir o poeta e a poesia em um lugar privilegiado, mesmo em relação à filosofia, pois

não é oficio de poeta narrar o que aconteceu; é, sim, de representar o que poderia acontecer, quer dizer: o que é possível segundo a verossimilhança e a necessidade. Com efeito, não diferem o historiador e o poeta por escreverem verso ou prosa (...) diferem, sim, em que diz um as coisas que sucederam, e outro as que poderiam suceder. Por isso a poesia é algo de mais filosófico e mais sério do que a história, pois refere aquela principalmente o universal, e esta o particular. (ARISTÓTELES, 1987, p. 209). 
A partir deste diálogo entre os pensamentos de Platão e Aristóteles podemos sumariamente considerar que tanto a situação da filosofia quanto a da literatura e como, de certo modo, a interação entre ambas passa a ser considerada pelo olhar da filosofia e que passa, de certo modo, por uma estrutura hierarquizada.

A possibilidade de uma campo de estudo comum à literatura e à filosofia - que envolva arte e conceito - não é, de modo algum, um terreno novo à história da filosofia - embora hoje muitas vezes o pareça, através da fragmentação do saber e do crescimento da especialização. Desde já cabe apontarmos a título de ressalva, conforme melhor analisaremos ao longo do capítulo subsequente, que a relação que Blanchot estabelece com a filosofia se estabelece de maneira a determinar certas peculiaridades que não estariam presentes em outros filósofos, a exemplo de Espinosa, Kant ou mesmo Platão (HOPPENOT et MILON, 2010, p. 11).

Esta relação e a formação de um campo comum se estabelece na França nos moldes da formação de uma tradição desde a Modernidade (Cf. BADIOU, 2015, p.14), com as escritas de Rousseau, Voltaire e Diderot, por exemplo, guardadas as diferenças entre os autores e suas obras, assim como as inúmeras possibilidades de interação que os temas e abordagens que as concepções permitem em cada momento.

Restringindo ainda mais esta análise à contemporaneidade ${ }^{2}$ francesa esta relação parece se tornar ainda mais intensa (e talvez

\footnotetext{
2 Uma análise cronológica mais detida é realizada por Philippe Lacoue-Labarthe e Jean-Luc Nancy, conforme destaca Stéphane Marchand (MERLEAU-PONTY, 2006, p. 1419) que afirmam que a partir da segunda metade do século XVIII a literatura passou a ser compreendida conceitualmente conforme a fazemos hoje - o que os autores designarão como sendo o "absoluto literário".
} 
indiscernível e necessária), o que é percebido de modo muito nítido por Alain Badiou pois, para o autor, há "uma relação singular da filosofia com a literatura, que é uma característica surpreendente da filosofia francesa do século XX" (BADIOU, 2015, p. 14).

O modo como esta interação ocorre é problematizado pelos comentadores, mas podemos depreender que possuem um viés comum. Ao prosseguir em sua reflexão e diagnóstico Badiou afirma que:

Quase poderíamos dizer que um dos objetivos da filosofia francesa foi criar um novo lugar de escrita, no qual a literatura e a filosofia seriam indiscerníveis; um lugar que não seria nem a filosofia como especialidade nem exatamente a literatura, mas que seria uma escrita onde não se pode mais distinguir entre 0 conceito $e$ a experiência da vida. Porque, finalmente, essa invenção de escrita consiste em dar uma vida literária ao conceito. (BADIOU, 2015, p. 15).

Adiante retomaremos e pormenorizaremos esta relação entre conceito e experiência de vida mas - que também possui uma certa tradição para a produção do contexto que desejamos para esta tese - mas, por ora, cabe adentrarmos em uma questão que também está compreendida em maior profundidade - e que possui uma importância especial na ocasião de análise deste trabalho - qual seja: na interação entre filosofia e literatura, a formação de uma análise que não permita que uma se reduza à outra, sobrepujando toda e qualquer especificidade, e, também, que não seja necessária a escolha e preferência de uma entre as duas (aos moldes de "ou 
filosofia ou literatura"), através de uma análise de alternativa entre campos absolutos que são incapazes de se comunicar.

A partir da reconstrução deste cenário de debate na França contemporânea remete o pensamento de Blanchot a um lugar privilegiado:

Da alternativa entre filosofia e literatura, acabamos com uma transfiguração de ambas as práticas; é apropriado, devemos admitir, uma imagem filosófica da literatura. Esta imagem, no entanto, vai além do campo da filosofia e toca, de volta, a literatura. Essa fusão de literatura e filosofia em uma certa concepção de literatura, sua incandescência, foi levada a um ponto culminante por Maurice Blanchot, romancista, crítico, pensador entre as duas disciplinas. ${ }^{3}$

A amplitude desta questão dentro do pensamento de Blanchot será analisada detidamente nos capítulos seguintes, mas desde já cabe apontarmos para o modo como o autor é situado, por Stéphane Marchand - que assina o artigo da coletânea organizada por Maurice Merleau-Ponty - justamente "entre" a filosofia e a literatura.

3 Livre tradução de: "De I'alternative entre philosophie et littérature, nous aboutissons donc à une transfiguration des deux pratique; c'est le propre, il faut en convenir, d'une image philosophique de la littérature. Cette image, cependant, excède le seul champ de la philosophie et touche en retour la littérature. Cette fusion de la littérature et de la philosophie dans une certaine conception de la littérature, son incandescence, a été portée à un point culminant par Maurice Blanchot, romancier, critique, penseur entre les deux disciplines." (MERLEAUPONTY, 2006, p. 1425). 
Neste contexto de análise, no qual estabelecemos um panorama histórico da relação entre filosofia e literatura, cabe mencionarmos a ressalva que Frédéric Cossutta realiza a este respeito, no sentido de que são

dois tipos de discurso, literário e filosófico, considerando que suas respectivas identidades não são adquiridas, estão em questão, não são assim estabilizadas sob uma identidade essencializada e não podem ser seriamente consideradas sem levar em conta outros discursos ligados dentro de formações discursivas ${ }^{4}$

Auferindo, ainda, o autor a mesma dignidade aos discursos, reforçamos o intento de estabelecer uma análise aberta e não normativa e estável de tais questões, principalmente considerando a conjuntura específica que a presença da obra de Blanchot proporciona a este cenário. Adiante retomaremos esta questão, aprofundando a relação entre filosofia e literatura no pensamento do autor.

Ainda em relação aos elementos que constituem este cenário contemporâneo, cabe retomarmos e aprofundarmos que o modo como a relação entre o conceito e a experiência de vida são estruturados até permearem este momento de estudo. Desde já cabe anteciparmos que a relação da filosofia com a existência possui relevância não apenas para Blanchot, mas também e especialmente

\footnotetext{
${ }^{4}$ Livre tradução de: "deux types de discours, littéraire et philosophique, en considérant que leur identité respective n'est pas acquise, est en question, n'est donc pas stabilisée sous une identité essentialisée et ne saurait être sérieusement envisagée sans prendre en compte d'autres discours liés au sein des formations discursives" ( COSSUTTA, 2005, p. 6).
} 
para a relação que se pretende realizar com o pensamento de Emmanuel Lévinas.

Neste sentido, podemos apontar que há um grande esforço por parte dos pensadores que compõem filosofia francesa do século XX na análise de Badiou em "Mostrar que o conceito é vivo, que é uma criação, um processo e um acontecimento, e que, a esse título, ele não é separado da existência" (BADIOU, 2015, p. 17).

A ocasião histórica e social vivida na França no período em que Blanchot escreve, conforme analisaremos adiante, intensifica esta relação necessária entre conceito e existência ${ }^{5}$. Ocorre que, se remetermos à análise realizada por Beaufret (Cf. BEAUFRET, 1976) em seus estudos a respeito das filosofias da existência - a exemplo de Kierkegaard e Heidegger - podemos considerar que estes pensadores influenciaram fortemente a França contemporânea e recriam um contexto muito semelhante ao anteriormente aqui diagnosticado por Badiou no que se refere à relação entre existência e conceito.

${ }^{5}$ As análises de Blanchot ao estabelecer críticas à literatura contemporânea percorrem o argumento de que, em certa medida, a literatura se configuraria neste momento como um além da literatura, como uma experiência existencial: "essa necessidade que a literatura contemporânea tem de ser mais do que literatura: uma experiência vital, um instrumento de descoberta, um meio para o homem de se pôr à prova, de se tentar, e nessa tentativa buscar ultrapassar os seus limites. (...) literatura para uma experiência verdadeira: experiência de si mesmo, experiência de seus pensamentos, não para guardá-los, e confirmá-los, menos ainda para com eles persuadir os outros, mas para afastá-los, mantê-los a distância, "experimentá-los" confiando-os a uma outra existência, isto é, para alterá-los, desmenti-los." (BLANCHOT, 2011, p. 222-224). Assim, a experiência enquanto existência encontra-se no cerne da estrutura da Filosofia Francesa Contemporânea, assim como possui grande relevância para o pensamento de Blanchot. 
A análise realizada por Beaufret remete às origens da filosofia e, antes de ser um período filosófico que estaria compreendido entre os séculos XIX e XX, entre Kierkegaard e JeanPaul Sartre, o existencialismo seria, antes, uma postura filosófica que remeteria a Aristóteles e a Pascal, por exemplo.

Assim, Beaufret separa a história da filosofia em duas linhagens: uma buscaria "elucidar a estrutura geral do todo da existência" (BEAUFRET, 1976, p. 11) e estruturaria um sistema que apenas ao final chegaria ao homem; já a oura linhagem trataria diretamente do homem e da sua existência (sendo esta, segundo o autor que se filiaria propriamente o existencialismo). Assim, ainda que de modo mais ou menos acentuado, a filosofia, em grande medida para o autor, se ocuparia da questão da existência, ainda que esta não seja a intenção imediata dos seus pensadores.

A partir disto, não estamos definir Blanchot - ou mesmo Lévinas - como um existencialista, mas apenas acrescentar à presente leitura que parte dos filósofos que formam o nosso contexto de análise possuem a influência direta de pensadores para os quais a existência é assunto primordial, de modo a endossar a profundidade das raízes da relação estabelecida entre existência e conceito, entre literatura e filosofia, de modo que aquela também se dê como uma questão a esta:

Desejávamos não uma separação clara entre vida e conceito, não que a existência como tal fosse submetida à idéia ou à norma, mas que o próprio conceito fosse um caminho de que não conhecemos forçosamente o objetivo. (BADIOU, 2015, p. 19). 
Ainda que esta contexto aparentemente estabilizado caberia apontarmos a análise realizada por Isabelle Kalinowski (KALINOWSKI, 2001 , p. 2) a qual, no artigo intitulado "A literatura no campo filosófico francês na primeira metade do século XX - $O$ caso de Jean Wahl e Hölderlin", situa neste período o campo filosófico francês na esfera institucional, junto às universidades e publicações ligadas às revistas educacionais.

Tal localização também seria responsável por situar a própria literatura dentro do campo filosófico, tema que retomaremos de forma ainda mais relevante em outros momentos de nosso trabalho, de modo que, apenas na segunda metade do século - a partir de nomes como o de Jean-Paul Sartre e o advento da revista "Les temps modernes" - que os conceitos da literatura parecem passar a ser legítimos de constarem como objeto de estudos dentro do campo filosófico.

O esboço desta questão nos remete à relação (e também à tensão) formada entre literatura e filosofia em Blanchot, conforme veremos adiante.

Por ora, cabe apontar que os exemplos de pensadores que subsidiam a relevância desta interação - antes mesmo de adentrarmos ao pensamento de Blanchot, de Lévinas e de outros não faltam, de modo que a aproximação em direção à literatura por parte dos filósofos através da produção literária ou por sua teorização - a exemplo de Jean-Paul Sartre, Michel Foucault, Jacques Derrida, entre outros.

\footnotetext{
${ }^{6}$ Livre tradução de: "La littérature dans le champ philosophique français de la première moitié du XXe siècle - Le cas de Jean Wahl et de Hölderlin" (KALINOWSKI, 2001).
} 
Assim, de modo a prosseguir na reconstrução do contexto de nosso recorte, cabe situarmos o debate em meio aos outros pensadores com os quais Blanchot dialoga.

\section{2 - Interlocutores privilegiados}

Pelas razões que adiante analisaremos mais detidamente, relacionar Blanchot a outros pensadores passa por questões inerentes ao próprio estilo de escrita do pensador mas, por ora, o importante é compreendermos a amplitude do campo de debate ao qual o autor se propõe.

O estudo mais aprofundado a respeito dos interlocutores de Blanchot pode passar diversas instâncias de análise: os autores que o influenciaram ou foram influenciados por Blanchot e as menções e críticas que Blanchot realiza em suas obras. Com isto, intentamos vislumbrar e possibilitar a abertura para o diálogo com outros pensadores contemporâneos, a exemplo de Lévinas, que será realizado aqui de modo mais intenso, bem como o de reestruturar um contexto específico - no tocante não apenas à filosofia, mas também à literatura -, uma vez que o espectro de autores com os quais Blanchot dialoga é amplo e diversificado, as possibilidades de recortes que propõem relacionar o pensamento de Blanchot a outros autores são inúmeros e passam por: Hegel, Rilke, Mallarmé, Nietzsche, Kafka, Lévinas, Duras, Derrida, Hölderlin, Sartre, Bataille, entre tantos outros.

A partir deste panorama tão plural o que podemos considerar inicialmente - ponto que retomaremos adiante - é modo como Blanchot transita pelos terrenos da literatura e da filosofia de 
modo indistinto, afirmando a tenuidade de uma possível separação entre estes campos ${ }^{7}$.

Em relação a estes interlocutores de Blanchot o recorte de nosso trabalho direciona, de modo imediato, à relação do autor com Emmanuel Lévinas. Antes de prosseguirmos com esta questão devemos, nesta ocasião, realizar um apontamento a respeito de influência filosófica no pensamento de Blanchot .

Quando da análise da influências literárias e filosóficas de Blanchot, Jean-Philippe Miraux destaca especialmente três nomes: Mallarmé, Hegel e Nietzsche (MIRAUX, 1998, p. 11-21). Conforme apontamos anteriormente, a menção a Mallarmé é recorrente nos textos críticos de Blanchot mas, uma vez que nossos estudos se situam na perspectiva filosófica, cabe superficialmente apontarmos para a leitura blanchotiana de Hegel e Nietzsche.

Os temas presentes nestes autores e que ecoam no pensamento de Blanchot são dois e que estão em relação: a dialética hegeliana e o eterno retorno nietzchiniano - ou, nos termos de Blanchot, "pensar a presença como todo e o todo domo presença" e "nomear a lei do Eterno Retorno" (BLANCHOT, 2016, p.39).

\footnotetext{
7 De modo a melhor desenvolver esta afirmação, podemos mencionar a articulação proposta por Etienne Pinat do modo como Blanchot mobiliza alguns pensadores a partir da análise do conceito de morte, um dos grandes temas do autor e que, inclusive, o relacionam a Lévinas: "em relação à linguagem e à escrita literária, ela se desenvolve na leitura de obras literárias (as de Kafka, Mallarmé, Rilke, Dostoiévski, Batalha, Hölderlin, Char, Camus, Leiris ...), bem como na apropriação e contestação de pensamentos filosóficos (os de Hegel, Kerkegaard, Nietzsche, Heidegger, Sartre, Simone Weil, Emmanuel Lévinas ...)" - livre tradução de "comme liée au langage et à l'écriture littéraire s'y développe dans la lecture d'ouvres littéraires (celles de Kafka, Mallarmé, Rilke, Dostoiévski, Bataille, Hölderlin, Char, Camus, Leiris...) ainsi que dans l'appropriation et la contestation de pensées philosophiques (celles de Hegel, Kerkegaard, Nietzsche, Heidegger, Sartre, Simone Weil, Emmanuel Lévinas...)." (PINAT, 2014, p. 20).
} 
Tais elementos já são responsáveis por proporcionar um direcionamento inicial à leitura de Blanchot, que carrega, em uma breve análise para o momento, as marcas de negatividade e da ausência de repouso - o que emerge de modo mais intenso nas obras mais tardias de Blanchot (em especial em "O passo além" - 1973) e coadunam com o recorte temático proposto em nosso trabalho.

Conforme apontamos inicialmente, embora a questão da comunidade seja o ponto articulador de nosso trabalho para a aproximação do pensamento de Blanchot e Lévinas, a questão do neutro e do fora permeiam toda este estudo e remetem a questões relevantes à análise do pensamento destes autores. Embora retomemos a influência de Hegel e Nietzsche mais adiante, quando da análise da escrita de Blanchot, cabe reafirmarmos um apontamento realizado por este em relação a Nietzsche em "Reflexões sobre o niilismo" presente em "A conversa infinita":

Com Nietzsche a filosofia se abala. Não será apenas por ser ele o último dos filósofos (cada um sendo sempre o último) Ou talvez porque, chamado por uma linguagem totalmente outra, a escrita de ruptura, cuja vocação seria supor as "palavras" apenas riscadas, espaçadas ou cruzadas no movimento que as afasta, mas que por esse afastamento as retém como lugar da diferença (...) (BLANCHOT, 2007, p. 113)

Assim, em linhas gerais, a menção a Nietzsche e ao eterno retorno evoca a concepção de ruptura - que adiante será melhor analisada em conjunto com a concepção de fragmentário. 
Ainda em suas reflexões presentes em "A conversa infinita" ao analisar a estrutura histórica contemporânea em "A questão mais profunda", Blanchot a faz através da dialética e por meio de uma leitura que merece aqui ser reproduzida integralmente, de modo a oferecer às análises que realizaremos adiante sobre a escrita de Blanchot:

Mas, para a dialética, não há questão terminal. Onde terminamos, começamos. Onde começamos, só começamos de fato se o começo está novamente no final de tudo, ou seja, o resultado o produto - do movimento do todo. É a exigência circular. O ser se desdobra como o movimento girando em círculo, e esse movimento vai do mais interior ao mais exterior, da interioridade não desenvolvida à exteriorização que o aliena, e dessa alienação que 0 exterioriza até a plenitude realizada e reinteriorizada. (BLANCHOT, 2010, p. 47)

O movimento dialético, assim como aquele provocado pelo eterno retorno, é, de certo modo, retomado por Blanchot ao longo de sua obra - e de um modo muito específico em relação ao modo como o autor concebe não apenas a linguagem da escritura, mas também a sua própria linguagem e escrita.

Em uma última consideração em relação aos interlocutores de Blanchot neste momento de nosso trabalho, ressaltamos que compõe o cerne de nosso trabalho a proposta de estabelecer um diálogo entre Blanchot e Lévinas, que será devidamente proposto, 
uma vez que a própria presença deste autor possibilita diversos recortes temáticos.

Assim, vai sendo esboçado o cenário no qual o pensamento de Blanchot se insere e ao qual outras características se somarão adiante, de modo que podemos passar ao momento subsequente de nosso texto, pormenorizando algumas questões históricas e políticas que também são responsáveis por compor uma análise mais detida do momento contemporâneo.

\section{3 - As questões levantadas pela conjuntura história e política}

Cabe, ainda, apontar para mais uma especificidade do recorte proposto em nosso trabalho. Conforme acompanharemos mais adiante, grande parte dos temas e das respectivas discussões elencadas ao longo deste trabalho se concentram sobre a obra "Comunidade inconfessável" publicada inicialmente em 1983.

Deste modo, ainda que o foco principal de nossa análise não seja propriamente a política em Blanchot, o contexto histórico e político anterior ao da produção da obra deve ser relembrado. Neste sentido, dois fatos se sobressaem: a Segunda Guerra Mundial (1939 1945) e Maio de 1968.

A Segunda Guerra e os horrores dos campos de concentração nazistas possuem um grande impacto no pensamento contemporâneo - não se restringindo exclusivamente ao pensamento de Blanchot - o que podemos apontar nas teorias contemporâneas e de modo mais significativo em Jean-Paul Sartre, Michel Foucault, Jacques Derrida, e também em uma tradição formada por Theodor W. 
Adorno, Walter Benjamin, Max Horkheimer, Hannah Arendt, entre tantos outros. Assim, a subjetividade, a alteridade, as questões sociais permeiam o pensamento de tais filósofos, assim como a iminência de questões políticas.

Especialmente me Blanchot, a Segunda Guerra o aproxima assim como o seu pensamento - de modo muito peculiar a Emmanuel Lévinas não apenas em relação a seu pensamento, mas principalmente pela qualificação de ser também um pensador judeu fato que abordaremos mais de modo mais detido adiante. O contexto no qual estes pensadores estão imersos é invocado de modo explícito por Lévinas poucas e precisas vezes e merece aqui ser relembrado na ocasião em que reflete o sofrimento - e o seu mal neste período histórico:

Século que, em trinta anos, conheceu duas guerras mundiais, os totalitarismos de direita e de esquerda, hitlerismo e stalinismo, Hiroshima, o goulag, os genocídios de Auschwitz e do Cambodja. Século que finda na obsessão do retorno de tudo o que estes nomes bárbaros significam. Sofrimento e mal impostos de maneira deliberada, mas que nenhuma razão limitava na exasperação da razão tornada política e desligada de toda a ética. (LÉVINAS, 2004, p. 138).

A crítica aos horrores do período caminham para a proposta de compreensão do pensamento de Lévinas, que passa pela a ética a filosofia primeira para Lévinas -, e não pela ontologia - vigente para o pensamento da época e que retomaremos adiante. 
Soma-se a este contexto histórico as questões políticas impossíveis de serem dissociadas - inclusive do campo literário que, como bem analisa $\mathrm{BUCLIN}^{8}$, recria um campo que não é estranho ao campo político. Neste sentido vale ressaltarmos que, embora o recorte temático aqui presente se aproxime da política, cabe apontarmos que não aprofundaremos esta questão diretamente, tendo em vista ser uma questão que por si só mereceria todo um estudo e trabalho unicamente a ela dedicada - abordagem que melhor situarmos na ocasião de aprofundarmos o conceito de comunidade.

Meramente com a intenção de situar o pensamento de Blanchot no cenário político de sua época, é de conhecimento que este se aproximava, no início de sua vida intelectual, à extrema direita francesa (Cf. BUCLIN, 201., p. 33, entre outros) mas, neste período, já podemos afirmar que a sua escrita não se esgotava na política, muito ao contrário, a crítica à literatura é o que se destaca para os críticos deste período - o que, para Buclin (2011, p. 37), seria responsável por atribuir certa ambiguidade ${ }^{9}$, inclusive em relação aos

\footnotetext{
${ }^{8}$ Nas palavras do autor: "o campo literário nunca é totalmente alheio ao campo político, muito menos no período imediato do pós-guerra, quando o PCF ocupa um lugar preponderante no pecado dos corpos literários resultantes da Resistência, ao que além disso tem É uma ajuda decisiva para o Ocupação, uma vez que detém uma posição de liderança nos grandes debates que irão pontuar a vida intelectual do país" - livre tradução de "le champ littéraire n'est jamais totalement étranger au champ politique, à plus fort raison dans l'immédiat après-guerre où le PCF occupe une place prépondérante au sin des instances littéraires issues de la Résistance, auxquelles il a d'ailleurs fourni une aide marérielle déterminante pensanr l'Occupation, de même qu'il tient une place de premier choix dans les grands débats qui rythmeront la vie intellectuelle du pays." ( BUCLIN, 2011, p. 21)

${ }^{9}$ Segundo o autor: "A ambigüidade, em Blanchot, é o que afeta o real quando está preso entre as malhas da ficção. E a literatura mais realista não pode escapar do fenômeno que torna instável quando os encaminhamentos para a realidade são parasitados pelo próprio status do texto ficcional." - livre tradução de "L'ambiguïté,
} 
seus posicionamentos políticos, e que seria marcante para o pensamento de Blanchot - tema relevante para a ocasião de pensarmos a relação entre filosofia e literatura no pensamento do autor - e inerente à própria concepção de literatura, ao "espaço literário" e ao conceito de "neutro", que são temas centrais de Blanchot.

Assim, nosso trabalho, pelo próprio recorte temático aqui proposto, tangencia as questões políticas - em certa medida muitas vezes criando a possibilidade mesma de estruturar determinados posicionamentos políticos para os autores. Assim, ainda que algumas questões sejam latentes para a análise da comunidade - a exemplo do Comunismo e de maio de 68 - que estão no bojo da concepção blanchotiana, oportuna e pontualmente remeteremos a estas questões, especialmente no que concerne à presença de Lévinas para tais contribuições de tomadas de posição de Blanchot.

chez Blanchot, c'est ce qui affecte le réel lorsqu'il est pris entre les mailles de la fiction. Et la litterature la plus réaliste ne saurait échapper à ce phénomène qui rend instable le seuns lorsque les référents revoyant à la réalité sont parasités par le statut même du texte de fiction." (BUCLIN, 2011, p. 39) 


\section{Capítulo 02 - A escrita de Blanchot ou como escrever sobre Blanchot sem traí-lo}

Neste momento de nosso trabalho, que intenta prioritariamente formar a base para o desenvolvimento do nosso recorte temático, há a intenção de analisar o modo como a escrita peculiar de Blanchot o situa de uma forma específica no cenário da Literatura e da Filosofia francesa contemporânea.

Para tanto, neste capítulo, passaremos por alguns comentadores de Blanchot que são responsáveis por estabelecer uma determinada leitura do pensador e que pretendemos melhor analisar adiante.

Assim, neste capítulo, melhor compreendendo o pensamento de Blanchot, o realizaremos a partir de um percurso que passará por três pontos principais: o modo como se estabelece a presença de Blanchot no cenário intelectual francês contemporâneo, a partir disto analisaremos uma possível estrutura da obra de Blanchot a partir da perspectiva da fragmentação e, por último, analisaremos especificamente a relação da filosofia e da literatura na obra deste pensador. 


\section{1 - A presença de Blanchot no cenário francês contemporâneo}

A presença de Blanchot no cenário intelectual da França se estende amplamente e possui maior ou menor produtividade entre os anos de 1933, momento em que ingressa como escritor na revista "Le Rempart" até o ano de sua morte em 2003. O estudo de seu pensamento se iniciou de modo mais intenso recentemente - em parte também em razão de seu ineditismo-, principalmente no Brasil $^{10}$, é de extrema relevância para a estruturação intelectual deste contexto, dialogando com filósofos e literatos - conforme já apontamos anteriormente a respeito dos interlocutores privilegiados.

Assim, o pensamento de Blanchot é consagrado como uma "obra fundamental de nosso tempo"11.

Embora possua uma presença considerável, a figura de Blanchot, assim como seu pensamento, trazem consigo uma aparente incoerência em relação a este cenário pois carregam em si o que fica caracterizados por seus comentadores como obscuro e fragmentado o que adiante analisaremos mais detidamente-, inviabilizando, de certo modo, a aproximação ao seu pensamento, principalmente por parte do grande público.

A menção à breve apresentação de Blanchot presente na maioria de seus livros - "Maurice Blanchot, romancista e crítico, nasceu em 1907. Sua vida foi inteiramente dedicada à literatura e ao

\footnotetext{
${ }^{10}$ A exemplo das produções nacionais, temos a dissertação de mestrado "Maurice Blanchot e a Literatura - uma experiência outra" de Marcela Moura Almeida em 2012 pela PUC - SP; "Escrever, morrer: Estudos sobre a imagem da morte nos ensaios de Maurice Blanchot" de Aline Magalhães Pinto em 2013 pela PUC - RJ; "A questão do sentido na ficção de Maurice Blanchot" de Daniel Barbosa Cardoso em 2014 pela UNB entre outros.

${ }^{11}$ Livre tradução de: "oeuvre fondamentale de notre temps" (COLLIN, 1986, p. 19).
} 
silêncio que the é próprio." (BLANCHOT, 2013, p.III) - é realizada de modo recorrente por seus estudiosos para ilustrarem a presença de sua ausência.

Em relação a este modo específico de se fazer presente do autor, assim como a forma através da qual isto se relaciona à sua obra e à sua escrita, Julien Dugnoille na obra "O desejo de anonimato em Blanchot, Nietzsche e Rilke" ${ }^{12}$ introduz sua tese a respeito do desaparecimento (desaparecimento castrador, para este comentador) da subjetividade e de rompimento com um determinado modelo de identidade destes escritores a partir de suas próprias obras - o que pode ser relacionado à "ausência" de Blanchot no cenário contemporâneo a partir da própria composição de sua escrita, o que veremos mais detidamente adiante na ocasião de análise de seu estilo.

Em tal ocasião Dugnoille relaciona Blanchot à sua obra além de tangenciar a questão da comunidade de forma muito sutil afirmando que o autor:

Tenta, nesse sentido, "postular" desta comunidade (talvez indizível) de artistas e autores, o que seria um reflexo da bela chama dessa ociosidade pela expulsão do eu criado. (...) Blanchot inclui, em seu espaço literário, um grande número de autores que, por esse desejo de romper com uma certa forma de identidade, nos permitirão ilustrar, até

12 Título original: "Le désir d'anonymat - chez Blanchot, Nietzsche et Rilke" (DUGNOILLE, 2004). 
mesmo enriquecer, nossa reflexão sobre esse desejo de anonimato. ${ }^{13}$.

A partir análise há um campo para a afirmação de que a ausência de Blanchot - ou mesmo a sua obscuridade - se estabeleceriam intencionalmente e de modo seu pensamento, talvez em parte por sua influência surrealista presente em "Thomas, o obscuro" e que influenciaria a sua obra a partir de então.

É neste sentido, de maneira bastante crítica ao pensamento de Blanchot que Henri de Monvallier e Nicolas Rousseau rechaçam a obscuridade criada pelo pensador ao estabelecer uma persona que seria responsável pela inconsistência de seu pensamento - de modo que a obscuridade não seria racionalizável, mas sim ocasionaria meramente uma confusão.

No livro intitulado "Blanchot L'obscur ou La Déraison Litteraire" Monvallier e Rousseau analisam a figura de Blanchot e o tomam por "um filósofo sem pensamento" 14 considerando, inicialmente, que o "propósito filosófico do autor" seria um tanto quanto "confuso"15.

13 Livre tradução de: "tente-t-il, en ce sens, de "postuler" à partir de cette communauté (peut-être inavouable) d'artistes et d'auteurs, ce qui relèverait de la fine flamme de ce désoeuvrement par l'expulsion du moi qui crée. (...) Blanchot inclut, dans son Espace littéraire, un nombre conséquent d'auteurs qui, par cette volonté de rompre avec une certaine forme d'identité, nous permettront d'illustret, voire d'enrichir, notre réflexion sur ce désir d'anonymat." (DUGNOILLE, 2004, p. 13).

14 Livre tradução de: "Um philosophe sans pensée" (MONVALLIER et ROUSSEAU, 2015, p.117)

15 No original: "(...) c'est que son propos est plutôt confus." (MONVALLIER et ROUSSEAU, 2015, p.119) 
Neste sentido, sem que aprofundamos o mérito das aproximações realizadas por Monvallier e Rousseau, cabe destacarmos que, a respeito da relação entre Filosofia e Literatura, Blanchot participaria, de certo modo, dos dois, da seguintes forma: "Nem verdadeiramente literatura (mas preferencialmente reflexão sobre a literatura), nem verdadeiramente filosofia (pois desprovida de argumentação verdadeira), a obra de Blanchot joga em ambos registros permanecendo em um estilo híbrido."16.

No texto que abre a obra "Maurice Blanchot et la philosophie" organizada por Éric Hoppenot e Alain Milon, o último escreve o texto Entre Blanchot et la philosophie estabelecendo, justamente, linhas da relação compreendida entre Blanchot e a Filosofia, considerando o que o "e" pode compreender.

O texto inicial da obra de Hoppenot e Milon tem um ênfase semelhante à que pretendemos estabelecer neste momento do nosso texto e que melhor desenvolveremos adiante, qual seja, de investigar as diversas possibilidades de interação entre Blanchot e a Filosofia.

Quanto a isto, os questionamentos de Blanchot em relação ao Neutro (e, principalmente, ao conceito de Fora), conforme melhor analisaremos adiante, ganharão relevância para a Filosofia, em razão do modo como este se estrutura - e que retomaremos adiante - mas que ao mesmo tempo também não se esgotam nela: "Nós diremos, então, quer para acessar ao Neutro, quer para o nomear ou para o entender, para o fazer acessar a uma forma -

16 Livre tradução de: "Ni vraiment littérature (mais plutôt réflexion sur la littérature), ni vriamen tphilosophie (car dénuée de véritable argumentation), l'oeuvre de Blanchot joue sur les deux registres en permanence dans un style hybride." (Cf. MONVALLIER et ROUSSEAU, 2015, p.137). 
necessariamente particular - de visibilidade, é necessário sair da filosofia."17.

Embora sem definir uma "classificação" para Blanchot neste momento, Milon realiza uma importante constatação a respeito da obra do autor, qual seja:

Escritura filosófica, escritura literária, escritura poética? Talvez os três juntos! Pouco importa, porque as escrituras ricas são plurais. Elas mostram que não há uma escritura filosófica, mas escrituras filosóficas. Porém, uma coisa é certa. Blanchot não está no sistema filosófico no sentido tradicional do termo; ele é na correspondência, não aquela da forma epistolar, mas a de base. ${ }^{18}$.

Em linhas gerais, o posicionamento impediria e mesmo prejudicaria a própria concretização do intento intelectual de Blanchot, de modo que, ao analisarmos detidamente a obra deste pensador "teremos apenas a confirmação de que o pensamento do

\footnotetext{
${ }^{17}$ Livre tradução de: "On dira alors que pour accéder au Neutre, pour le nommer, pour l'entendre, pour le faire accéder à une forme - forcément particulière - de visibilité, il faut sortir de la philosophie." (MARTY, 2009, p. 86).

${ }^{18}$ Livre tradução de: "Écriture philosophique, écriture littéraire, écriture poétique ? Peutêtre les trois réunies! Peu importe d'ailleurs car les écritures riches sont plurielles. Elles montrent qu'il n'y a pas une écriture philosophique, mais des écritures philosophiques. Une chose est sûre cependant. Blanchot n'est pas dans le système philosophique au sens classique du terme; il est dans la correspondance, pas celle de la forme épistolaire mais celle de la strate." (MILON, 2010, p. 5).
} 
impossível é impossível" ${ }^{19}$ e produziria um contexto argumentativo que, em certa medida, beiraria a irracionalidade.

Conforme observaremos ao longo de nosso texto, nossa análise não coaduna com tal posicionamento. Ao aprofundarmos os estudos sobre a estrutura de escrita - em especial o caráter fragmentário - de Blanchot também podemos perceber o modo como os aspectos criticados por Monvallier e Rousseau constituem a peculiaridade do pensamento blanchotiano.

Retornando à questão do ostracismo de Blanchot frente também à comunidade de intelectuais de seu tempo - a exemplo de Tzvetan Todorov, Philippe Lesnard e Martlène Zarade (Cf. REGNIER, 2007 , p. 16) - é originada a partir da própria estrutura do texto de Blanchot e que foi, em certa medida, melhor recebida no campo da Filosofia mais do que da Literatura:

A agudeza de suas análises, a estranheza e complexidade de seu trabalho fazem de Blanchot um autor amplamente ignorado pelo "público em geral" e admirado por muitos intelectuais, tanto na França quanto no exterior. Se ele adquiriu certa notoriedade, não é graças aos críticos literários, mas sim a toda uma geração de filósofos que constantemente comentam sobre isso e reivindicam uma dívida em relação a ele (Deleuze, Derrida, Foucault, Levinas, Nancy) ${ }^{20}$

\footnotetext{
${ }^{19}$ Livre tradução de: "on aura simplement eu la confirmation que la pensée de l'impossible est elle-même impossible" (MON VALLIER et ONFRAY, 2015, p. 27)

${ }^{20}$ Livre tradução de: "L'acuité de ses analyses, l'étrangeté et la complexité de son oeuvre font de Blanchot un auteur à la fois largement ignoré par le $<<$ grand public > > et admiré par de nombreaux intellectuels, tant en France qu'à l'étranger.
} 
O esboço de tal contexto seria responsável por conferir a Blanchot a condição de "solidão essencial": "solidão, talvez, que não pode ser explicada na medida em que é incomensurável"21. Assim, ainda que incomensurável, não se estabeleceria um caráter de irracionalidade à sua obra como algo menor, mas sim como uma proposta própria ao seu pensamento.

Ainda em continuidade à situação do pensamento de Blanchot, Hadrien Buclin ressalta que, embora Blanchot se recuse a efetivamente participar do meio literário francês - no sentido de uma recusa principalmente a assumir uma posição de destaque em relação às manifestações públicas e institucionais -, Blanchot se estabelece como

um dos representantes mais emblemáticos de um pequeno pólo de produção intelectual, governado sobretudo por processos de consagração simbólica e não comercial, nos círculos literários franceses da segunda metade do século $X X .^{22}$.

S'il a acquis une certaine notoriété, ce n'est pas grâce aux critiques littéraires, mais plutôt à toute une génération de philosophes qui ne cesse de le commenter et de revendiquer une dette à son égard (Deleuze, Derrida, Foucault, Levinas, Nancy)." (HOPPENOT, 2015, p. 163).

${ }^{21}$ Livre tradução de: "solitude, peut-être, dont on ne peut rendre compte dans la mesure où elle est incommensurable." (REGNIER, 2007, p. 16).

22 Livre tradução de: "un des représentants les plus emblématiques d'un pôle de production intellectuelle restreint, régi avant tout par des processus de consécration symbolique plutôt que commerciale, au sein des milieux littéraires français de la seconde moitie du XXe siècle." (BUCLIN, 2011, p. 10). 
Sua escrita, transitando entre a crítica e a literatura, e que deve ser analisada em razão de sua própria estrutura - conforme adiante melhor analisaremos - é responsável por influenciar de modo decisivo escritores, artistas e filósofos no contexto denominado como "French Theory" pela tradição norte-americana (BIDENT, 2009, p. 104).

Ainda através da análise do pensador realizada por este autor esta recusa em se fazer presente denotaria uma certa coerência da postura de Blanchot em relação ao seu pensamento, a literatura, marcada pela ruptura e autonomia (texto) guardaria uma relação intrínseca com a sua vivência (contexto) - relação que se estabelece de modo ainda mais evidente na ocasião de analisarmos esta interação sob a perspectiva da fragmentação - do mundo e da linguagem.

A caracterização da obra de Blanchot como "hermética" também é recorrente nos apontamentos realizados por seus comentadores designaria a dificuldade de adentrar e compreender o seu pensamento - talvez mais pela forma a que o autor se propõe a adotar do que propriamente o seu conteúdo, conforme analisaremos adiante.

No mais, a reconstrução deste contexto passa também, de certo modo, pela própria situação da filosofia neste cenário e que nos remeteria fim da filosofia - anunciado por Heidegger ${ }^{23}$ e considerado no texto de Lévinas sobre Blanchot ${ }^{24}$, de modo que

\footnotetext{
${ }^{23}$ A este respeito: "Blanchot não apenas re-age ao gesto (filosófico) da delimitação da filosofia, mas também dá um lugar privilegiado a Hegel, Nietzsche, Heidegger e Lévinas. A filosofia em sua delimitação (finitude) é, portanto, duplamente o coração de seu pensamento e de sua escrita." - livre tradução de: "(...) non seulement Blanchot re-joue le geste (philosophique) de la délimitation de la philosophie, mais il accorde aussi une place privilégiée à Hegel et Nietzsche, Heidegger et Lévinas. La
} 
Nossa época, portanto, leva ao extremo a demanda pelo fim da filosofia, mas também traz consigo uma renovação e um enriquecimento histórico da pesquisa filosófica. Nosso tempo reconcilia radicalmente a filosofia com sua própria disparidade, assegurando ao mesmo tempo ainda sua sobrevivência pela multiplicação de suas formas e campos de investigação. ${ }^{25}$

Assim, se estabelece um cenário no qual a própria filosofia levaria a seu fim - o que é observado por Blanchot no texto "Notre compagne clandestine" (1980) e também em "L'écriture du desastre" (Cf. BLANCHOT, p. 158-159) e que é relacionado a um movimento semelhante na literatura e que é, em certa medida, analisado pelo

philosophie en sa délimitation (finition) même se trouve donc doublement au coeur de sa pensée et de son écriture." (HARLINGUE, 2009, p. 28).

${ }^{24} \mathrm{Na}$ ocasião de seu texto sobre Blanchot, Lévinas considera a respeito do pensamento daquele autor que: "(...) no entanto, ele não tende à filosofia. Não que seu propósito seja inferior a tal medida - mas Blanchot não vê na filosofia a possibilidade última, nem, além disso, na própria possibilidade - no "eu posso" - o limite do humana. Este século terá sido para todos o fim da filosofia" - Livre tradução de "Et cependant il ne tend pas à la philosophie. Non pas que son dessein soit inférieur à une telle mesure - mais Blanchot ne voit pas dans la philosophie I'ultime possibilité, ni, d'ailleurs, dans la possibilité elle-même - dans le «je peux » - la limite de I'humain. Ce siècle aura donc été pour tous la fin de la philosophie" (LÉVINAS, 1975, p. 9-10).

${ }^{25}$ Livre tradução de: "Notre époque porte donc à l'extrême l'exigence de la finde la philosophie, mais elle porte aussi en elle un renouvellement et un enrichissement historiques de la recherche philosophique. Notre époque reconcuit de façon radicale la philosophie à sa propre disparitin tout en assurant pourtant sa sur-vie par la démultiplication de ses formes et de ses champs d'investigation." (HARLINGUE, 2009, p. 25). 
pensador desde 1959, em "O livro por vir" a partir da questão "para onde vai a literatura?"26.

\section{2 - A fragmentação}

Aprofundar a análise da escrita de Blanchot - ainda, de certo modo, em continuidade com o subcapítulo anterior - é um ponto articulador tanto para a melhor compreensão de Blanchot dentro do cenário intelectual quanto para melhor analisarmos a relação entre literatura e filosofia no interior de seu pensamento - e, sob este aspecto, podemos considerar a questão da fragmentação como um elemento relevante para iniciarmos este percurso.

A análise do estilo de escrita de Blanchot por si só mereceria um capítulo a parte, principalmente em razão de sua relevância para melhor compreendermos a presença de Blanchot no cenário intelectual, conforme procuramos delinear outrora.

Cabe ressaltar, em relação à especificidade do fragmento, expressamente, que "Fragmento não é aforismo"27 - de modo que o que há é um princípio fragmentário, contrário à totalização

Assim, para os principais comentadores do autor a fragmentação de seus textos é o principal aspecto a ser ressaltado quando - o que intentamos observar a partir disto é - justamente o modo como a opção pelo fragmentário acaba por alcançar a estrutura

${ }^{26} \mathrm{Em}$ tal obra Blanchot analisa o desaparecimento da literatura e propõe o seguinte: "Às vezes nos fazem estranhas perguntas; esta, por exemplo: 'Quais são as tendências da literatura atual?' Ou então: 'Para onde vai a literatura?' Sim, pergunta espantosa, mas o mais espantoso é que, se há uma resposta, esta é fácil: a literatura vai em direção a ela mesmem direção À sua essÊncia, que é o desaparecimento." (BLANCHOT, 2013, p. 285).

${ }^{27}$ Livre tradução de: "Le fragment, ce n'est pas l'aphorisme." (HILL, 2007, p. 79). 
temática de Blanchot - em especial a relação como a forma se estabelece como necessária para a composição do conteúdo que se verifica como objeto de seus estudos.

Ainda antes de aprofundarmos esta análise, cabe realizarmos um apontamento a título de constatação no que se refere aos diferentes gêneros literários percorridos por Blanchot ao longo da produção do extenso conjunto de suas obras.

Assim, embora por parte dos comentadores de Blanchot seja possível a categorizações da obra de Blanchot a partir de dois aspectos, de gênero literário e cronológico, com a intersecção entre ambos, neste primeiro momento analisaremos brevemente apenas em crítica e obra literária - embora sob a ressalva de que há uma gama de possibilidade na articulação entre ambos.

Neste contexto, suas obras ficcionais, a exemplo de "Thomas, o obscuro" (sendo a primeira versão de 1941) e "Aminadab" (1942), que compõem o Blanchot romancista, possuem forte influência surrealista e jogam, literariamente, com os limites da realidade (e da própria literatura) - o que, por si só, já seria possível de se relacionar ao recorte aqui proposto.

Em relação aos romances de Blanchot, embora neste trabalho estejamos mais próximos ao Blanchot crítico, aqui compreendido em sentido amplo, tanto relacionado à análise literária quanto à filosófica, é relevante apontarmos algumas questões mais gerais e que corroboram com a nossa proposta de análise, uma vez que a marca de sua proposta está presente também em sua obra ficcional.

Buclin, ao analisar a obra ficcional do autor em comento, aponta que duas marcas principais presentes em seus livros e que compõem o cerne da escrita blanchotiana: "Esse trabalho de 
ambiguidade e estranheza está no coração do estilo blanchotiano, do qual ele é, por assim dizer, o princípio matricial." ${ }^{28}$.

Tal caracterização da escrita do autor são responsáveis por introduzir a temática do neutro e a concepção de fora - o que adiante exploraremos mais detidamente -, o que é intensificado a partir da compreensão da extensão do fator fragmentário do autor que passamos a realizar.

A afirmação de que há uma relação entre forma e conteúdo na escrita de Blanchot, no sentido de que o estilo de escrita de Blanchot engendra os seus temas principais, assim como o objeto de seu estudo requer uma determinada forma de apresentação aparenta uma afirmação que aparenta uma certa trivialidade para qualquer estudo que se proponha de modo mais aprofundado e rigoroso em relação a qualquer autor. Ocorre que, em Blanchot, a extensão desta relação se estabelece quase que nos moldes a propor uma experiência ao leitor - experiência mesma da ruptura e da proposta do fora conforme concebida pelo autor ${ }^{29}$.

Ocorre ainda que tal proposta se aproxima o autor de outros dois filósofos bastante influentes para Blanchot: Hegel - a través da Dialética - e Nietzsche - com o Eterno retorno, que possuem uma estrutura muito próxima em seu modo de articulação

\footnotetext{
${ }^{28}$ Livre tradução de: "Ce travail de l'ambiguïté et de l'étrangeté s'inscrit au coeur même du style blanchotien dont il est pour ainsi dire le princié matriciel." (BUCLIN, 2011, p. 81)

${ }^{29}$ Christophe Samarsky sintetiza bem a relação da tematização do fragmentário e a/na própria escrita de Blanchot. Para este autor, a linguagem em Blanchot "não é um veículo ou o instrumento de uma autoridade subjetiva de brainstorming. Esta linguagem é a ordem da apresentação das coisas, mesmo por si só, sem dinstincções palavra / coisa que é uma abstração" - livre tradução de:"il n'est pas un véhicule, oul'instrument d'une instance éconciatrice subjective. Ce langage est l'ordre de la présentations des choses même par elles-mêmes, sans dinstinctions mot/chose qui est une abstraction." (SAMARSKY, 2011, p. 97-98).
} 
em relação ao fragmentário, "Porque para a dialética, primeiro, o fragmento não é: o fragmento é o nome dado a tudo quando não pode ser dito" 30 .

Assim, a influência do pensamento de Nietzsche, que se permeia pela relação com o eterno retorno, marcado pelo próprio estilo de escrita do filósofo

Em Nietzsche haveria duas palavras: uma que pertence ao discurso contínuo, coerente e sistemático da filosofia; e outra que fica de fora: descontínua, plural, intermitente, inacabado, palavra do intermediário, do limite e ao limite, que não é unificada, não é suficiente para si mesma, não conhece a contradição, e que está inscrita além de todo horizonte, seria a do ser ou do mundo como tudo. ${ }^{31}$

Deste modo, a escrita de Blanchot o coloca, segundo seus comentadores, em uma posição ainda mais próxima à influência dos filósofos acima mencionados:

\footnotetext{
${ }^{30}$ Livre tradução de: "Car pour la dialectique, d'abord, le fragment n'est pas: le fragment, c'est le nom que se donne le tout quant il n'arrive ni à se dire" (HILL, 2007, p. 78).

${ }^{31}$ Livre tradução de: Chez Nietzsche, il y aurait donc deux paroles: I'une qui appartient au discours continu, cohérent, systématique de la philosophie; et une autre qui reste en dehors: discontinue, plurielle, intermittnete, inachevée, parole de l'entre-deux, de la limite et à la limite, qui n'estpas unifiée, ne se suffit pas à ellemême, ne connaît pas la contradiction, et qui s'inscrit au-delà de tout horizon, serait-ce celui de l'être ou du monde comme tout. (HILL, 2007, p. 81).
} 
A impossibilidade de uma escrita fragmentária, sua necessária interpenetração com um discurso dialético que é a figura oposta, provavelmente significa que o fragmentário, sendo a inscrição anterior, arquivística e descontínua, também está lá vindo não cumprido do fora. O fragmentário está assim ligado à afirmação e à lei do eterno retorno do mesmo. ${ }^{32}$.

O advento do fragmentário não se daria como uma característica inerente unicamente ao terreno da linguagem - ou, mais precisamente, ao da escritura - mas estaria presente na própria concepção de mundo de Blanchot, que se apresentaria já de modo fragmentário, competindo à escritura a "responsabilidade de restaurar o fragmentário em seu primeiro status" 33 e perfazendo e aperfeiçoando, em certa medida, uma movimentação semelhante ao Eterno Retorno e à Dialética.

Assim, o fator fragmentário em suas obras encontra inerente relação a temas centrais do pensamento blanchotiano - a exemplo do Neutro, do Fora e da própria concepção de Sujeito, além da própria relação entre Filosofia e Literatura e que reconfiguraria a própria obra - "O trabalho fragmentário não se reduz a um gesto singular de escrita, cria um novo leitor, que se perde, procura a perda, provavelmente assombrado e assombrado pela

\footnotetext{
32 Livre tradução de: "L'impossibilité de l'écriture fragmentaire, sa nécessaire interpénétration avec un discours dialectique qui en est la figure contraire, signifie sans doute que le fragmentaire, tout en étant l'antérier, l'inscription archivale et discontinue, est aussi là venir non advenu de l'oeuvre. Le fragmentaire est donc lié à l'affirmation et à la loi de l'éternel reour du même." (SAMARSKY, 2011, p. 24) 33 Livre tradução de: "responsabilité de restituer le fragmentaire dans son statut premier " (SAMARSKY, 2011, p. 21).
} 
irrevogabilidade neutro" ${ }^{34}$. Neste sentido, podemos considerar "a dialética atribuída por Blanchot a Hegel é descrita como uma linguagem, como um modo determinado a se relacionar com um interlocutor." ${ }^{35}$.

Em "O passo além" a questão do neutro e do fragmento é proposta nos seguintes termos:

\begin{abstract}
A escrita fragmentária é a escrita da repetição, da variação, talvez uma arte da fuga. O narrador joga tanto com a epanortose quanto com o paradoxo, e aqui encontramos os atributos do neutro. (...) Se a escrita fragmentária é o lugar privilegiado para fazer ouvir o que é da espera é bom porque pode interromper a duração pela repetição. ${ }^{36}$.
\end{abstract}

Na obra de Blanchot o fragmentário se faria nos moldes de uma exigência, que proporcionaria de modo único a relação com o

\footnotetext{
${ }^{34}$ Livre tradução de: "L'oeuvre fragmentaire ne se réduit pas à un singulier geste d'écriture, par là, elle crée un nouveau lecteur, qui ne cesse de se perdre, de rechercher la perte, susceptible de hanter et d'être hanté par l'irrévocabilité du Neutre." (HOPPENOT, 2006, p. 35).

35 Livre tradução de: "la dialectique attribué par Blanchot à Hegel est décrite comme un langage, comme un mode déteerminé d'entrer en rapport avec un interlocuterus." (FRIES, 1999, p. 8)

${ }^{36}$ Livre tradução de: "L'écriture fragmentaire est bien l'écriture de la répétition, de la variation, peut-être un art de la fugue. Le narrateur joue tout autant avec l'épanorthose que le paradoxe, et nous retrouvons ici les attributs du neutre. (...) Si l'écriture fragmentaire est le lieu privilegié pour faire entendre ce qu'ilen est de l'attente c'est bien parce qu'elle peut interrompre la durée par la répétition." (HOPPENOT, 2006, p. 31)
} 
Fora e o Neutro. Em "O passo além", obra fragmentária de Blanchot este considera que

O fragmentário, talvez, se enuncie, no melhor dos casos, em uma linguagem que não o reconhece. Fragmentário: não querendo dizer nem o fragmento, parte de um todo, nem o fragmentário em si. O aforismo, a sentença, máxima, citação, pensamentos, temas, células verbais estando talvez mais distanciados do fragmentário do que o discurso infinitamente contínuo que tem por conteúdo a <<sua própria continuidade>>, continuidade que não se assegura por ela mesma senão se dando por circular e, por este turno, se submetendo ao prévio de um retorno cuja lei está no fora, fora este que é fora da lei. (BLANCHOT, 2016, p. 70)

Deste modo, é justamente o fragmentário que aperfeiçoaria a intenção de uma "a escrita que se poderia dizer fora do discurso, fora da linguagem" (BLANCHOT, 2010, p. 8) - tema este que retomaremos quando do aprofundamento de nossa análise em relação ao pensamento de Lévinas.

Ocorre que esta análise da escrita de Blanchot passa, ainda, pela análise mais ampla de suas obras, que possuem gêneros textuais mais bem definidos até chegar em suas obras finais fragmentárias se localiza em meio a outros argumentos e pode gerar uma questão em relação à própria situação do pensamento de Blanchot não apenas em relação à sua localização no cenário intelectual francês, conforme analisado no sub-capítulo anterior, mas 
também em relação à articulação de filosofia e literatura em seu pensamento, conforme veremos adiante.

\section{3 - Filosofia e Literatura em Blanchot}

Escrever sobre filosofia e literatura em Blanchot se estabelece de modo não apenas a ser um objeto de estudo para este pensador mas, principalmente, percorre a composição de suas obras.

Inicialmente, podemos observar, de modo mais amplo, dois grandes movimentos que se estabelecem na leitura de Blanchot e que adiante serão mais detalhadamente estudados: um primeiro, que estabelece uma determinada forma dos comentadores de Blanchot lerem e analisarem a sua obra - que porventura podem provocar uma leitura por vezes normativa, classificativa e estabilizante (classificando Blanchot como filósofo ou não) - o que notadamente não é nossa intenção

Neste contexto, nossa tentativa é de realizar um panorama um tanto quanto problematizador - analisando, mais do que com a intenção de classificar, o modo como esta questão repercute no pensamento de Blanchot - e em especial no que isto implica em sua relação com Lévinas - e considerando "a singularidade de Blanchot no espaço do pensamento filosófico" ${ }^{37}$, mais do que o literário.

Não são poucas as possibilidade de análise deste tema dentro da obra de Blanchot, sendo a primeira possibilidade o modo como Blanchot lida com a ficção e a suas obras de não ficção - que

37 Livre tradução de: "la singularité de Blanchot dans l'espace de la pensée philosophique." (REGNIER, 2007, p. 16) 
apenas referenciaremos neste momento como "teóricas" ou as que refletem de modo amplo ${ }^{38}$ a respeito do "espaço literário"

Iniciando esta análise, Annelise Schulte Nordholt estuda a obra de Blanchot a partir do que a autora denomina como sendo um "verdadeiro bilinguismo" que pode ser analisado sob o prisma não expressamente da relação entre filosofia e literatura, mas mais especificamente entre a análise teórica crítica e a ficção

O trabalho de Maurice Blanchot é o produto de um conflito, de uma tensão que o atravessa. (...) Isso conclui não apenas 0 assunto de um questionamento teórico amargo nos ensaios críticos, Mas ainda está no centro da escrita do próprio Blanchot, uma escrita ecológica, no sentido de que, durante muitos anos, ela procura o caminho duplo dos ensaios críticos e da ficção. ${ }^{39}$.

38 De modo a subsidiar esta leitura ampla que os comentadores de Blanchot realizam sob a a concepção de "téorico" temos que: "para alguns, o trabalho "teórico" de Blanchot desenvolve uma reflexão filosófica ou um pensamento ético; para outros, expõe antes uma reflexão política - questionar a lei incessantemente; para outros, é uma teoria da literatura ..." - livre tradução de "por les uns, l'oeuvre $<<$ théorique >> de Blanchot développe une réflexion philosophique, ou une pensée éthique; pou d'autres, elle expose plutôt une réflexion politique - questionnant incessamment la loi; pour d'autres encore, il s'agit d'une théorie de la littérature...." (FRIES, 1999, p. 7)

39 Livre tradução de: "L'oeuvre de Maurice Blanchot est le produit d'un conflit, d'une tension qui la traverse de part en part.(...) Ce conclit non seulement fait l'objet d'un questionnement théorique acharné dans les essais critiques, mas encore il se trouce au centre de l'écriture même de Blanchot, écriture ecpérimentale au sens où, pendant de longues années, elle se cherche à travers la double voie des essais critiques et de la fiction." (NORDHOLT, 2007, p. 85). 
Esta duplicidade seria responsável por localizar a escrita de Blanchot em um "gênero indefinível"40 - tal premissa de análise da obra de Blanchot faz com que a autora estruture a totalidade de sua obra em três momentos distintos (NORDHOLT, 2007, p. 86): o primeiro englobaria as obras dos anos quarenta - exemplificadas através de Faux pas e La Part du feu e mesmo da obra de ficção de estréia de Blanchot, Thomas l'obscure - nas quais ensaio e ficção formariam dois gêneros distintos; já o segundo momento caracterizado pela autora como um "entre" o primeiro e terceiro momentos, mais bem definidos, que, - a exemplo de L'Entretien infini - e que Blanchot experimentaria diversos estilos e escrituras até a estruturação de um terceiro momento, que marcaria o contraste em relação ao primeiro e se concentraria nas obras dos anos setenta e oitenta, marcadas pelo encontro dos ensaios e ficções na escrita fragmentária de Blanchot - a exemplo de Pas au delá e L'Écriture du désastre - processo considerada pela autora como uma "evolução".

Já Olivier Harlingue (Cf. HARLINGUE, 2009, p. 43-44) aponta, a partir de uma análise cronológica das obras de Blanchot e em linhas gerais, dois momentos nitidamente divergentes: o primeiro estaria contido entre Faux pas e Livre à venir e consagraria um momento de análise próprio à literatura - tanto à crítica quanto à experiência literária. Já no segundo momento, contido entre Le Pas au-delà e L'Ecriture du désastre, haveria uma dupla divisão marcante para o pensamento de Blanchot - e que conteria, por um lado, a análise do fenômeno literário através de uma problematização filosófica geral e, por outro, a apresentação do fragmentário como forma da escritura destacada da literatura e da filosofia - sendo possível relacionar aos estudos de Biden, por exemplo.

${ }^{40}$ Livre tradução de: "genre indéfinissable" (NORDHOLT, 2007, p. 85). 
Neste sentido, a obra "Le Pas au-delá" (1973) pode ser compreendida "com sua alternância entre fragmentos filosóficos e fragmentos narrativos, marca a culminação de uma evolução dupla que começou no início dos anos 60: de um lado, o fim da história, do outro, do discurso crítico." 41 - enquanto "Conversa infinita" (1969) chegaria, de fato, a um "pensamento propriamente filosófico"42 - em consonância com o pensamento de Lévinas, de Heidegger e de Bataille também, a partir de uma - "crítica da metafísica ocidental" ${ }^{43}$.

Ocorre que tais análises de seus comentadores também acabariam por, em última análise, remeter a uma certa aporia - "os textos fictícios de Blanchot levantam questões que lembram muitas questões literárias e filosóficas." ${ }^{44}$. Deste modo, retomando o anteriormente considerado a respeito da própria relação entre Filosofia e Literatura na França podemos considerar que

Embora a obra de Blanchot esteja essencialmente no registro da crítica e da ficção, a filosofia sempre esteve no centro de seu questionamento, afirmando que "filosofia é a própria vida" ou que seria nosso companheiro para sempre, de dia, de

\footnotetext{
41 Livre tradução de: " avec son alternance entre fragments philosophiques et fragments narratifs, marque l'aboutissement d'une double évolution qui s'est amorcée dès le début des années soixante: d'une part la fin du récit, de l'autre celle de la parole critique." (NORDHOLT, 2007, p. 95)

42 Livre tradução de: "pensée proprement philosophique" (NORDHOLT, 2007, p. 95).

${ }^{43}$ Livre "critique de la métaphysique occidentale"(NORDHOLT, 2007, p. 95).

${ }^{44}$ Livre tradução de: "les textes fictionnels de Blanchot soulèvent des interrogations qui rappellent de nombreaux questionnements tant littéraires que philosophiques." (cf. HURAULT, 1999, p. 11).
} 
noite, perdendo seu nome, tornando - se literatura". ${ }^{45}$.

Assim, especificamente em relação ao pensamento blanchotiano, cabe apontarmos que não entraremos no mérito de uma divisão de Blachot em períodos - o que no terreno da filosofia não é frequente, enquanto no da literatura - e em especial às obras ficcionais de Blanchot, isto ora seria analisado como um todo, desde suas obras e escritos iniciais até os finais, sem qualquer ruptura (cf. HURAULT, 1999, p. 8), possuindo um fio condutor estruturado de modo diversos conforme os comentadores.

Algumas questões se intensificam ou se estabelecem de modo mais latente em determinadas obras. Em relação à obra ficcional de Blanchot: " persistiremos, portanto, no estabelecimento de uma unidade geral, mesmo que para cada texto se imponha uma particularidade" ${ }^{46}$, o que deve ser considerado concebendo a escrita de Blanchot como genuinamente estabelecida sob a perspectiva do fragmentário, da dialética e do eterno retorno.

Para além de uma estrutura que contemple suas obras de modo cronológico e estruturado - o que, em princípio, seria contrário ao próprio fator fragmentário de sua obra - remete a um ponto mais profundo em relação às meras reivindicações de Blanchot filósofo ou Blanchot literato, que estabeleceriam certas peculiaridades ao

\footnotetext{
${ }^{45}$ Livre tradução de: Si l'oeuvre de Blanchot s'incrit esentiellement dans le registre de la critique et de la fiction, la philosophie a toujoues été au coeur de son questionnement, déclarant que $<<$ la philosophie était la vie même $>>$ ou qu'elle $<<$ serait notre compagne à jamais, de jour, de nuit, fusse en perdant son nom, en devenant littérature >>. (HOPPENOT, 2015, p. 163).

${ }^{46}$ Livre tradução de: on persistera donc à établir une unité d'ensemble même si chaque texte s'impose comme cas particulier" (cf. HURAULT, 1999,p. 8)
} 
pensamento deste autor, conferindo um posicionamento específico de Blanchot em relação à filosofia e à literatura

Considerar Blanchot, portanto, não é simplesmente reivindicá-lo por filosofia e apreciá-lo apenas nesses termos. Ele é um escritor de histórias em prosa e crítico literário, não um filósofo stricto sensu. É antes uma questão de definir a posição que Blanchot adota em relação a algumas questões filosóficas, uma posição que marca tudo o que ele escreve. ${ }^{47}$.

Tal análise abriria espaço para afirmações - a exemplo de "Todo mundo reconhece que Blanchot não é estritamente falando um filósofo"48 - que não desejamos afirmar em nosso trabalho - mas sim um passo inda mais elementar, também considerado por Hoppenot, no sentido pensar as estruturas elementares do pensamento de Blanchot e a partir de seu pensamento também - "Além do confronto com sistemas de pensamento, a filosofia trabalha em Blanchot, um lugar para pensar sobre a escrita literária."49.

47 Livre tradução de: "Considérer ainsi Blanchot, ce n'est pas simplement le revendiquer pour la philosophie et l'apprécier uniquement en ces termes. C'est un écrivain de récits en prose et de critique littéraire, pas un philosophe stricto sensu. Il s'agit plutôt de définir la position que Blanchot adopte face à quelquer questions philosophiques, une position qui marque tout ce qu'il écrit." (HART, 2009, p. 25) 48 Livre tradução de: "Tout le monde reconnaît que Blanchot n'est pas à proprement parler un philosophe." HOPPENOT, 2015, p. 164)

${ }^{49}$ Livre tradução de: "Au-dèla de la confrontation avec des systèmes de pensée, la philosophie oeuvre à Blanchot un lieu pour penser l'écriture littéraire." (HOPPENOT, 2015, p. 164) 
Este posicionamento, em um primeiro momento seria um pouco mais conservadora em relação às aproximações que Blanchot realiza em relação à filosofia, inclusive em relação à Comunidade inconfessável:

\begin{abstract}
Blanchot "usa" ou "fala com" a filosofia de uma maneira mais ou menos intensiva e, ao fazê-lo, desenvolve seu pensamento de escrever através de uma verdadeira peça em jogo na filosofia. (...) não só Blanchot não é e não pretende ser rigorosamente um filósofo (no sentido acadêmico e termo professoral-profissional), mas, acima de tudo, ele se esforça explicitamente para jogar com ou o filosofia sem fazer o seu jogo ${ }^{50}$
\end{abstract}

A partir desta perspectiva desejamos afirmar através da propositura desta questão que não intentamos realizar uma proposta de categorizar ou classificar o pensamento de Blanchot, estagnando-o como um literato ou como um filósofo, mas mais apresentar um campo de discussões profundas e profícuas - ponto que será reforçado a partir de diversas abordagens ao longo do nosso trabalho e que também se estabelece como um ponto de articulação em relação ao pensamento de Lévinas.

\footnotetext{
${ }^{50}$ Livre tradução de: "Blanchot $<<$ utilise >> ou $<<$ dialogue avec >> la philosophie de façon plus ou moins intensive et, ce faisant, élabore sa pensée de l'écriture à travers une véritable mise en jeu du tout de la philosophie. (...) non seulement Blanchot n'est pas et ne prétend pas être à proprement parler un philosophe (au sens univeritaire et professoral-professionnel du terme) mais, aussi et surtout, il s'efforce explicitement de jouer avec ou de la philosophie sans faire son jeu" (HARLINGUE, 2009, p. 17).
} 
Coadunando com este posicionamento, Roger Laporte, que estuda a relação entre filosofia e literatura no pensamento de Blanchot, vislumbra uma estrutura de escrita que não se esgotaria nem na literatura, nem na filosofia, criando uma terceira forma (intitulada como "scriptographie" - MACLACHLAN, 2009, p. 261) e que se relacionaria à fragmentação anteriormente analisada, no sentido de que:

A pesquisa de Blanchot, na qual o espaço literário e a escrita filosófica se encontram, encontra seu apogeu em seus escritos fragmentários, nos quais a literatura e a filosofia nunca deixam de unir e desvendar elos. ${ }^{51}$

Assim, a posição seria uma não posição, uma aporia em relação à filosofia e à literatura - sem intenção de apresentar exatamente uma solução categórica, mas mais a intenção de apresentar as relações e rupturas entre os campos no pensamento de Blanchot (Cf.HOPPENOT, 2015, p. 164) e "esses autores não serão estudados por si mesmos, mas porque emprestam seu horizonte ao pensamento estudado, não sem receber dele, de qualquer maneira, algum questionamento." 52 .

${ }^{51}$ Livre tradução de: "Cette recherche de Blanchot - où se rencontrent I'space littéraire et l'écriture philosophique - trouve son acmé dans ses écrits fragmentaires, où littérature et philosopie ne cessent de nouer et de dénouer des liens." (HOPPENOT, 2015, p. 164)

52 Livre tradução de: Ces auteurs ne seront donc pas étudiés pour eux-mêmes, mais parce qu'ils prêtent leur horizon à la pensée étudiée, non sans recevoir de celle-ci, d'alleurs, qulque questionnement." (COLLIN, 1986, p. 22) 
Assim, podemos afirmar que a relação de Blanchot com a filosofia é uma "relação particularmente complexa"53, pois: "A difícil receptividade de um estudo filosófico do trabalho de Blanchot deve-se aos três modos de exposição - literário, crítico, filosófico - que envolve, às posições que defende e ao seu estilo." ${ }^{54}$.

Frente a isto, considerando nossas análises prévias, tanto tem relação a um contexto geral como sobre o fragmentário, o fim da literatura e da filosofia, e a estrutura de escrita blanchotiana, podemos afirmar que a própria escrita de Blanchot intenta construir um outro - pautado pela ruptura e incerteza, considerando o poder mortal da palavra - (cf. FRIES, 1999, p. 9) caracterizando o discurso como destruidor assim que ele fala, jogando a todo momento com o fora de si mesmo e não se esgotando na tentativa totalizante da filosofia, cuja questão central se faria nos moldes conceituais, de modo que se torna "difícil dizer, por muitas razões, se existe um sistema filosófico em Blanchot, um sistema cuja missão essencial é estabelecer e estabilizar um pensamento." 55 .

Assim, nem a Filosofia, nem a Literatura seriam capazes de, isoladamente, construírem o espaço proposto por Blanchot, uma vez que

Ler Blanchot de uma maneira filosófica é renunciar ao risco literário, recuperar as regiões

\footnotetext{
${ }^{53}$ Livre tradução de: "relation particulièrement complexe" (CHOPLIN, 2015, p. 91). 54 Livre tradução de: La difficile recevaibilité d'une étude philosophique de l'oeuvre de Blanchot tient tant au triple mode d'exposition - littéraire, critique, philosophique - qu'elle comporte, qu'aux positions qu'elle défend, et à son style." (COLLIN, 1986, p. 12)

${ }^{55}$ Livre tradução de: "Mais il est difficile de dire pour de multiples raisons s'il existe un système philosophique chez Blanchot, système dont la mission essentielle est d'asseoir et de stabiliser une pensée." (HOPPENOT et MILON, 2010, p. 12).
} 
tranquilizadoras da verdade, continuar a endossar a literatura como o dócil servidor da ordem filosófica. ${ }^{56}$

Por outro lado podemos considerar que afirmar que Blanchot não é um filósofo - assim como não classificá-lo unicamente como um literato - Ihe garante uma certa independência para questionar e criticar a literatura e a filosofia e, uma vez que a filosofia é incapaz de esgotar conceitualmente a existência, uma vez que esta é, propriamente, uma experiência (MORA, 2009, p. 347)

A aparente contradição com a qual Olivier Harlingue encerra esta reflexão seria atribuída aos próprios traços de escrita do autor francês e, de certo modo, manteria uma determinada coerência em relação à sua estrutura de pensamento, em especial em relação ao neutro - que poderia ser analisada, neste aspecto, sob a influência de Hegel - pois, no momento em que nega a filosofia, também a afirma - o que estaria sob a guarda de um verbo transitivo, que requer um complemento, que se relacionaria à própria filosofia. Tal estrutura se relacionaria ao Neutro (o que retomaremos adiante de modo mais detido, em especial para a construção do pensamento de Blanchot em relação a Lévinas e para o conceito de comunidade).

A perspectiva de Blanchot, neste cenário, permite não apenas uma crítica, em sentido amplo, sobre a literatura, mas também sobre a própria filosofia (conf. HARLINGUE, 2009, p. 24) adicionar a idéia de "com" e não "e" ou "ou"

\footnotetext{
${ }^{56}$ Livre tradução de: "Lire Blanchot de manière philosophique, c'est renoncer au risque littéraire, regagner les régions rassurantes de la vérité, continuer de faire endosser à la littérature lerôle de servante docile de l'ordre philosophique." (MORA, 2009, p. 346).
} 
Sem sacrificar um ao outro, sem privilegiar um sobre o outro, Blanchot nos convida, na paciência e pânico da escrita (nem propriamente literária nem propriamente filosófica), a a indistinção radical e original da literatura e da filosofia, mostrando, assim, que os únicos diferem / divergem apenas no (s) fundo (s) sem fundo de uma "indiferença incalculável e imemorial. ${ }^{57}$

Tal posicionamento, por fim se relacionaria ao "nem... nem..." do neutro, sendo referência apenas para a própria literatura. A possibilidade de se pensar, ainda que filosoficamente o fora seria possível apenas pela via da literatura, não pela filosofia, para a qual o conceito de fora já estaria englobado nela mesma. - (HARLINGUE, 2009, p. 37) .

Considerando que, para Blanchot, a literatura apenas é capaz de fornecer a experiência do fora - e désoeuvrement ${ }^{58}$ - o que a filosofia, com a sua força totalizante, não conseguiria, por si só, proporcionar à experiência do pensamento (HARLINGUE, 2009, p. 3738).

\footnotetext{
57 Livre tradução de: "Sans déricer l'une de l'autre, sans privilégier l'une sur ou par rapport à l'autre, Blanchot nous invite, dans la patience et l'affolement de l'écriture (ni proprement littéraire ni proprement philosophique), à troucer l'indistiction radicale et originelle de la littérature et de la philosophiemontrant par là même que celles-si ne diffèren/divergent que sur le fond(s) sans fond(s) $d^{\prime}<<$ une $>>$ indifférence incalculable et immémoale." (HARLINGUE, 2009, p. 27)

${ }^{58} \mathrm{Em}$ nosso trabalho optamos por não traduzir a palavra "désoeuvrement" que, considerada em seu sentido literal seria algo próximo de "des-obra" ou "desobramento", perdendo, ao menos em parte, a intenção original contida em tal conceito, que remeteria também ao desdobramento.
} 


\title{
Capítulo 03 - A aproximação de Blanchot e Lévinas
}

\author{
Emmanuel Lévinas (1906 - 1995) foi um dos poucos,
} junto a Bataille, a ser considerado por Blanchot como um amigo além dos elementos trazidos em sua biografia e cujas relações pessoais foi bastante explorada por Christophe Bident em "Maurice Blanchot: partenaire invisible - essai biographique" (1998).

O conceito de amizade, no contexto formado por Lévinas e Blanchot - e, ainda, por Bataille -, passa a ser resignificado, adquirindo uma dimensão maior e que se relaciona, em certa medida, ao pensamento de Lévinas

\begin{abstract}
A história fala com o amigo porque ele não fala dele para reconhecer melhor a sua estranheza, não só o chamado destina-se a acolher o outro, é também o lugar onde o outro é convidado por sua vez a este em casa, onde ele é chamado para receber o outro com sua parte de desconhecido, ao se reconectar para querer conhecê-lo. ${ }^{59}$
\end{abstract}

\footnotetext{
${ }^{59}$ Livre tradução de: "Le récit parle à l'ami parce qu'il sair ne pas parler de lui pour mieux reconnaître son étrangeté; non seulement appel destiné à accueillir l'autre, il est aussi le lieu où l'autre est invité à son tour à cet accueil, où il est appelé à recevoir l'autre avec sa part d'inconnu en reconçant à voulour le connaître." (SANTI, 2007, p. 38)
} 
A respeito da amizade entre ambos ${ }^{60}$ esta é colocada em palavras por Danielle Cohen-Levinas nos seguintes dizeres:

Se este sentido é filosoficamente ou fictício evocado, ou na formação dos dois, no limiar de um ou outro, de um com o outro, entre eles, em uma ondulação contígua que é indetectável, é de fato a prova da emoção o que significa que volta ao extremo discurso. ${ }^{61}$

Assim, a própria relação entre ambos já se relacionaria, conforme veremos adiante, em certa medida, aos conceitos e interpretações que Ihes aproximam.

Embora haja esta proximidade pessoal entre os pensadores, sem adentrarmos em uma relação de causalidade desta relação sobre o pensamento, o respeito intelectual a Lévinas é notório: "meu amigo desde a minha adolescência e, certamente, um

${ }^{60}$ Amizade esta que se inicia na fase de formação de Blanchot: " Maurice Blanchot descobre afilosofia na Universidade de Estrasburgo, ele tem a chance de conhecer Emmanuel Levinas, sua amizade será infalível. Eles não param de comentar um ao outro e interagr em suas obras." - Livre tradução de: "Maurice Blanchot découvre la philosophie à l'université de Strasbourg, il a la chance d'y rencontrer Emmanuel Levinas, leur amitié sera indéfectible. Ils ne cesse ront de se commenter l'un l'autre et de dialoguer par oeuvres interposées." (HOPPENOT, 2015, p. 163).

61 Livre tradução de: "Que ce sens advuenne philosophiquement ou fictionnellement, ou encore dans lemaillage des deuz, au seuil de l'un ou l'autre, de l'un avec l'autre, entre eux, dans un frôlement contigu indémêlable, est bien la preuve du frisson de sens qui remonte à l'extrême ponte de la parole." (COHENLEVINAS, 2009, p. 76). 
dos filósofos mais profundos desta época, confirmaria suas reflexões em profundidade." ${ }^{12}$.

Assim, são estas raízes que a admiração por Lévinas conserva em Blanchot que este capítulo de nosso texto pretende melhor investigar - partindo das questões que se fazem inerentes ao próprio filósofo franco-lituano.

\section{1 - O entorno de Lévinas}

Inicialmente, cumpre esclarecer que 0 interesse de Blanchot por Emmanuel Lévinas não se exaure neste apenas como pensador, mas também - e, em relação a alguns temas específicos, poderíamos afirmar que, principalmente - como um pensador judeu. A partir desta afirmação a intenção de nosso trabalho não é a de reduzir o pensamento de Lévinas ao judaísmo - ou mesmo aos seus escritor sobre o judaísmo - o que seria contrario à postura adotada pelo próprio autor, mas sim a de mostrar uma importante dimensão de afetação que o "ser judeu" implica em seu pensamento, de modo que, a partir do momento que Lévinas é evocado nas obras e participa em grande medida da composição de uma estrutura maior do pensamento de Blanchot, uma idéia maior também é evocada junto com ele.

A exemplo disto, conforme já ressaltamos desde a nossa contextualização, temos a questão do judaísmo. Benny Lévy, em seus estudos sobre a presença do judaísmo em Lévinas, realizados na obra

\footnotetext{
${ }^{62}$ Livre tradução de: "mon ami depuis mon adolescence et, certainement, I'un des plus profonds philosophes de ce temps, confirmerait en profonderus vos réflexions." (BLANCHOT, 2009, p. 37)
} 
Être juif - Étude lévinassienne, destaca a implicação do ser judeu à formação do pensamento próprio a Lévinas, o que resultaria em uma análise interna ao pensamento do autor e que seria promovida a partir de um diálogo do autor consigo mesmo:

\begin{abstract}
Para o diálogo com Levinas pressupõe um diálogo de Levinas com Levinas, de Levinas, o pensador do retorno com Levinas philosopeu, de Levinas nascido na Lituânia com Levinas jogado no século, do esotérico Levinas, que permite dizer 0 significado bíblico do texto "filosófico" >>, com o exotérico Levinas ligado a erigir a separação entre seus textos "filosóficos" e seus textos "judaicos"63
\end{abstract}

Em relação às implicações que estes "dois Lévinas" possuem, cabe apontarmos ser uma questão que se propõe ao próprio autor - passando por atitudes de ordem prática, que concernem às diferentes editoras que Lévinas utilizava para publicar seus estudos sobre o judaísmo ou sobre filosofia - até questões que exigem uma reflexão mais aprofundada.

No mais, cabe ressaltarmos que, por diversas passagens, podemos considerar que Blanchot está atento não apenas às questões do judaísmo, mas mais precisamente às implicações de sua

63 Livre tradução de: "Car le dialogue avec Lévinas suppose un dialogue de Lévinas avec Lévinas, de Lévinas penseur du Retour avec Lévinas philosopeu, du Lévinas né en Lituanie avec Lévinas jeté dans le Siècle, du Lévinas ésotérique, qui laisse dire le sensé biblique das le texte <<philosophique>>, avec le Lévinas exotérique attaché à ériger lá séparation entre ses textes $<<$ philosophiques $>>$ et ses textes $<$ juifs>>." (LEVY, 2003, p. 17) 
condição, que estão arraigadas às vivências de Blanchot de tal modo que se fazem presentes em seu cotidiano.

Neste sentido podemos retomar as cartas trocadas nos anos de 1976 a 1998 entre Maurice Blanchot e Vadim Kozovoï (1937 - 1999) - poeta e tradutor de origem russa - nas quais há uma menção recorrente ao nome de Lévinas mais em relação à sua condição de estrangeiro do que propriamente a seu pensamento.

Assim, Blanchot se refere ao filósofo no seguinte sentido: "Quando Levinas se naturalizou francês (cerca de 35, acho), não o felicitei, parabenizei o país que o acolheu e assim enriqueceu de maneira prodigiosa." 64 .

Deste modo, a condição de Lévinas enquanto amigo (termo extremamente forte para Blanchot formando uma categoria à qual podemos somar talvez apenas o nome de Georges Bataille) confere à sua presença na obra de Blanchot uma situação específica em relação aos demais pensadores de sua época.

Benny Lévy capta, sinteticamente e ao menos em parte, o interesse de Blanchot nos judeus e das circunstâncias históricas que permeiam o judaísmo "Todo judeu é essencialmente um sobrevivente"65.

Assim, embora Lévinas possa ser considerado um filósofo, o fato de ser um pensador judeu, com publicações específicas neste campo não fogem do horizonte de análise da relação entre Blanchot e Lévinas, uma vez que sua existência é complexa e trouxe a Blanchot referências a experiências e relações que seriam "pré-filosóficas" - e

64 Livre tradução de: "Lorsque Levinas a été naturalisé français (vers 35, je crois), je ne l'ai pas félicité, j'ai felicité le pays qui l'accueillait et par là s'enrichissair d'une manière prodigieuse." (BLANCHOT, 2009. p. 122).

65 Livre tradução de: "Chaque Juif est essentiellement un survivant." (LEVY, 2003, p. 29). 
situaria o filósofo em uma situação peculiar: "Emmanuel Lévinas um pensador na encruzilhada de caminhos divergentes" (POIRÉ, 2007, p. 10), encruzilhadas e caminhos que seriam interessantes ao pensamento blanchotiano.

\section{2 - Reconstrução dos pressupostos filosóficos}

Antes mesmo de adentrarmos ao pensamento de Blanchot sobre Lévinas - ainda que optemos por manter um diálogo aberto entre os escritores ao longo de nosso trabalho - cabe reconstruirmos alguns pressupostos filosóficos a partir do pensamento de Lévinas - e não, neste momento, a partir da leitura que Blanchot realiza de sua obra.

Dentro da extensão da proposta desta tese obviamente cabe realizarmos um recorte sobre o pensamento de Lévinas e, para tal escolha, o faremos prioritariamente a partir da análise realizada por Blanchot no texto "A Literatura e o Direito à Morte" presente na coletânea "A parte do fogo", lançada em 1949.

A proposta deste recorte remete, imediatamente, à relação entre literatura e filosofia no pensamento de Blanchot, conforme abordamos anteriormente - principalmente pela menção ao pensamento de Lévinas

Abordar a relação de Lévinas e Blanchot pode se dar a partir de diversas abordagens ao longo das obras de ambos os pensadores - o que passa também pela própria estrutura de escrita de Blanchot, considerações que já realizamos anteriormente - e que se faria nos moldes de aproximações e distanciamentos - em especial em relação às concepções de Neutro e Outro (Cf. GARAMONT, 2011, p. 115), criando situações em que, embora "Blanchot e Levinas 
possam pensar o mesmo, é justo dizer que eles interpretam de forma bastante diferente." ${ }^{66}$ - em relação a tais assuntos, retomaremos adiante.

De modo a reconstruir algumas considerações a respeito do pensamento de Lévinas, o faremos a partir da seguinte estrutura: iniciaremos a partir do texto "Conhecimento do Desconhecido" presente em "A conversa infinita - A palavra plural" de Blanchot. A partir das indicações temáticas que Blanchot realiza neste texto, passaremos para o pensamento de Lévinas - não, necessariamente, a partir de Blachot, mas de forma a considerarmos o modo como o pensamento de Lévinas se estrutura.

Tal estrutura possibilitará que, adiante, retomemos o pensamento de Blanchot e novamente abordarmos as interações entre os pensadores. Assim, apenas adiante passaremos por considerações mais gerais a respeito deste ensaio de Blanchot, que se inicia com a indagação que remete a questões que se encontram no cerne de nosso trabalho: "O que é um filósofo?" (BLANCHOT, 2010, p.95).

O aprofundamento analítico que decorre desta questão leva Blanchot à observação de quatro movimentos distinto presentes no pensamento de Lévinas: o infinito, o desejo, o rosto e a linguagem. Antes de retomarmos para as considerações que Blanchot realiza a partir de uma leitura de uma movimentação que vai do conhecido para o desconhecido, cabe considerarmos o próprio pensamento de Lévinas.

Cabe, desde já, apontarmos que, embora estas passagens aparentem movimentos distintos, elas se encontram intrinsecamente

\footnotetext{
${ }^{66}$ Livre tradução de: "Dès lors, Blanchot et Levinas peuvent bien penser le même, il est juste de dire qu'ils l'interprètent tout autrement." (GARAMONT, 2011, p. 114)
} 
relacionadas, compondo a estrutura central do pensamento de Lévinas.

Inicialmente cabe considerarmos que o pensamento de Lévinas marcaria uma cisão no pensamento contemporâneo francês a partir do primado ético ${ }^{67}$ em detrimento do pensamento ontológico ${ }^{68}$ - conforme melhor explicitaremos, esta intimamente relacionada à análise proposta em nosso trabalho: "A filosofia ocidental foi, na maioria das vezes, uma ontologia: uma redução do Outro ao Mesmo, pela intervenção de um termo médio e neutro que assegura a inteligência do ser." (LÉVINAS,1988, p. 31).

No ensaio inaugural de "Entre nós: Ensaios sobre a alteridade" intitulado "A ontologia é fundamental?" Lévinas analisa a relação do pensamento presente no cenário contemporâneo com a estrutura proposta pela ontologia. Em "Outramente que ser ou paraalém da essência" - título original "Autrement qu'être ou au-delà de l'essence" (publicada apenas em 1990, mas que contém ensaios de períodos anteriores), ainda sem tradução para o português, a relação da ontologia e da ética já se encontra bastante sedimentada em seu pensamento, de modo que as tematizações dos problemas presentes

\footnotetext{
${ }^{67}$ A definição de ética de Lévinas merece aqui ser considerada: "Chama-se ética a esta impugnação da minha espontaneidade pela presença de Outrem. A estranheza de Outrem - a sua irredutibilidade a Mim, aos meus pensamentos às minhas posses - realiza-se precisamente como um pôr em questão da minha espontaneidade, como ética. A metafísica, a transcendência, o acolhimento do Outro pelo Mesmo, de Outrem por Mim produz-se concretamente como a impugnação do Mesmo pelo Outro, isto é, como a ética que cumpre a essência crítica do saber. E tal como a crítica precede o dogmatismo, a metafísica precede a ontologia." (LÉVINAS, 1988, p.30).

${ }^{68}$ A ontologia, por sua vez, como filosofia primeira seria "uma filosofia do poder" (LÉVINAS, 1988, p. 33) e também, em certa medida, da supressão do outro, e não uma filosofia da liberdade, como a ética possibilidade, de uma liberdade em relação à própria manutenção da alteridade.
} 
ao longo de sua obra se fazem de modo mais explícito: "O sujeito é compreendido inteiramente a partir da ontologia?"69.

Para respondermos a ambas as questões que interrogam a própria concepção de ontologia, assim como a relação é estabelecida com o sujeito neste contexto, a faremos a partir do pensamento do próprio Lévinas, que tece a seguinte consideração a respeito da abordagem da ontologia e da ética a partir da separação entre ambos como campos separados do saber:

Outrem não é primeiro objeto de compreensão e, depois, interlocutor. As duas relações confundemse. Dito de outra forma, da compreensão de outrem é inseparável sua invocação.

Compreender uma pessoa é já falar-lhe. pôr a existência de outrem deixando-a ser, é já ter aceito essa existência, tê-la tomado em consideração. (LÉVINAS, 2004, p. 27)

Assim, a Ética (pautada, de certo modo, pelas relações) pressuporia a Ontologia (pautada, então, pela existência), o que acaba por conferir aspectos peculiares ao pensamento de Lévinas - o que melhor analisaremos a respeito das considerações sobre 0 infinito, o desejo, o rosto e a linguagem, conforme apontado acima, mas que antes se torna necessário considerarmos as implicações da ética na formação do pressupostos para melhor compreendermos e delimitarmos a extensão de tais conceitos.

${ }^{69}$ Livre tradução de: "Le sujet se comprend-il jusqu'au bout à partir de I'ontologie?" (LÉVINAS, 2006, p. 54). 
Para tanto, nos restringiremos, principalmente às obras "Totalidade e infinito" (de 1961) e "Entre nós: Ensaios sobre a alteridade" (reunindo conferências entre 1951 e 1988) para explorarmos, neste primeiro momento, os movimentos observados por Blanchot e outras obra de modo mais pontual para o estudo do pensamento de Lévinas.

Como eixo articulador destes quatro movimentos podemos considerar a questão do Outro ou, mais precisamente, do Outrem, o absolutamente Outro, para, inclusive, relacionar este pensamento à Ética.

Para isto, compreender a posição que a subjetividade adquire na Ética de Lévinas e, principalmente, a sua relação com a alteridade, é primordial para compreendermos a extensão destes movimentos até mesmo para a construção do pensamento levinasiano.

Em relação à delimitação do conceito de Outrem, em resposta a uma entrevista a François Poirié sobre seu pensamento e o modo como a alteridade se fazia presente de modo reiterado, Lévinas afirma que

Mas antes de qualquer atributo, você é um outro que não eu, outro de outro modo, outro absolutamente! E é essa alteridade outra, alem daquela que se deve aos atributos, que é a sua alteridade; ela é logicamente não-justificável, logicamente indiscernível. (POIRIÉ, 2007, p. 86 87) 
O Outrem adquire o estatuto de superioridade em relação ao Eu, estabelecendo os moldes de uma estrutura intersubjetiva que se estabelece de modo bastante diverso em relação ao pensamento francês contemporâneo - o qual podemos concretizar, principalmente, na figura de Sartre ${ }^{70}$.

O encontro com outrem consiste no fato de que, apesar da extensão da minha dominação sobre ele e de sua submissão, não o possuo. Ele não entra inteiramente na abertura do ser em que já me encontro como no campo de minha liberdade. (LÉVINAS, 2004, p. 31)

O estatuto ético de Lévinas proporciona à figura o Outro uma posição de superioridade em relação ao Eu, o que é responsável por nos conduzir, para a sua melhor compreensão, a outros estudos a exemplo do rosto, da linguagem e da mortes, conforme melhor pormenorizaremos adiante.

Por ora, para cabe apontarmos, iniciando a observação dos movimentos propostos por Blanchot, que a questão do Infinito encontra-se no cerne da questão do Outrem, uma vez que a própria concepção de subjetividade é pautada por esta concepção - e não pela concepção de totalidade, de uma subjetividade restrita à sua estrutura, e marca que

\footnotetext{
${ }^{70}$ A estrutura das relações intersubjetivas apresentadas por Sartre em "O Ser e o Nada - Ensaio de Ontologia Fenomenológica" é marcada pela dominação e subjugação nas relações que o Ser-Em-Si-Para-Si, o Sujeito, estabelece com os outros e consigo mesmo. A ontologia sartriana é estruturada de modo bastante diverso da ética concebida por Lévinas, gerando também concepções diversas do estatuto da subjetividade.
} 
$\mathrm{Na}$ ideia do infinito pensa-se o que fica sempre exterior ao pensamento. (...) A relação com o infinito não pode, por certo, exprimir-se em termos de experiência - porque 0 infinito extravasa 0 pensamento que o pensa. (...) Mas se experiência significa precisamente relação com 0 absolutamente outro - isto é, com aquilo que extravasa sempre o pensamento - a relação com o infinito completa a experiência por excelência. (LÉVINAS, 1988, p. 13)

Há, neste sentido, uma mudança de uma estrutura de pensamento, que vai da estrutura de concepção da subjetividade enquanto totalidade, para a concepção de infinito. Neste sentido, a subjetividade é relacionada ao acolhimento de Outrem, de modo a conter mais do que pode conter.

Neste contexto, a crítica de Lévinas é direcionada a uma estrutura totalizante, pautada não pela estrutura da relação com Outrem, mas sim pelo Mesmo - o que pode ser corroborado com o argumento da irredutibilidade do Outro ao Mesmo a partir da estrutura da ética. Assim, é o Infinito (de Outrem) e a separação entre os termos que impossibilita a redução do que é absolutamente separado $^{71}$.

\footnotetext{
${ }^{71}$ Assim, a figura de outrem teria uma dimensão bastante específica dentro da estrutura do pensamento de Lévinas: "O Outro metafísico é outro de uma alteridade que não é fora, de uma alteridade que não é um simples inverso da identidade, nem de uma alteridade feita de resistência ao Mesmo, mas de uma alteridade anterior a toda a iniciativa, a todo o imperialismo do mesmo; outro de uma alteridade que constitui o próprio conteúdo do Outro; outro de uma alteridade
} 
O desejo, por sua vez, também se relaciona a esta estrutura, de modo a possibilitar uma abertura de um para além. Neste sentido, Lévinas não se refere apenas a uma configuração de um desejo de satisfação de algo ou de alguma falta (nos moldes de uma "necessidade"), mas sim a uma dimensão metafísica do desejo, que seria, justamente, um desejo que se furtaria à satisfação

O Desejo é desejo do absolutamente Outro. Para além da fome que se satisfaz, da sede que se mata e dos sentidos que se apaziguam, a metafísica deseja o Outro para além das satisfações, sem que da parte do corpo seja possível qualquer gesto para diminuir a aspiração, sem que seja possível esboçar qualquer carícia conhecida, nem inventar qualquer nova carícia. Desejo sem satisfação que, precisamente, entende o afastamento, a alteridade e a exterioridade do Outro. (LÉVINAS, 1988, p. 22)

Assim, a própria estrutura do desejo considera a alteridade, no sentido da transcendência.

Outro elemento trazido por Blanchot, que é o Rosto, parte mais exposta do Sujeito, e que confere a grandeza da dimensão da Ética levinalisana:

O rosto (visage) não é da ordem do visto, não é um objeto, é aquilo cujo aparecer conserva uma

que não limita o Mesmo, porque nesse caso o Outro não seria rigorosamente Outro: pela comunidade da fronteira seria, dentro do sistema, ainda o Mesmo. O absolutamente Outro é Outrem; não faz numero comigo." (LÉVINAS, 1988, p. 26). 
exterioridade que é também um chamado - ou um imperativo dado à sua responsabilidade. Encontrar um rosto é, de pronto, ouvir um pedido e uma ordem. (POIRIÉ, 2007, p. 85)

Assim, para Lévinas, o rosto já seria linguagem - a primeira, a originária - e discurso, já conteria, em si mesmo, uma epifania do rosto e dissimetria ${ }^{72}$ nas relações, o que impossibilita uma própria intenção totalizante da lógica do Mesmo e abre o espaço do infinito:

O rosto significa outramente. Nele, a infinita resistência do ente ao nosso poder se afirma precisamente contra a vontade assassina que ela desafia, porque totalmente nua - e a nudez do rosto não é uma figura de estilo, ela significa por si mesma. (LÉVINAS, 2004, p. 32)

O rosto traz consigo um imperativo ético - o "não matarás" e a responsabilidade (Cf. LÉVINAS, 2004, p. 216) pela parte mais desnuda e o que representa o impedimento da dominação e o convite ao acolhimento- "A tentativa da negação total, medindo o infinito desta tentativa e sua impossibilidade, é a presença do rosto. " (LÉVINAS, 2004, p. 32).

Assim, o rosto evocaria em si o infinito e também garantiria a própria ética

72 Cabe apontarmos que esta dissimetria não seria apenas oriunda e pautada pela concepção de "fora" mas, principalmente, pela "cima" - Cf. LÉVINAS, 1988, p. 153. 
O rosto, contra a ontologia contemporânea, traz uma noção de verdade que não é o desvendar de um Neutro impessoal, mas uma expressão: o ente atravessa todos os invólucros e generalidades do ser, para expor na sua $<<$ forma $>>$ a totalidade do seu $<<$ conteúdo $>>$, para eliminar, no fim das contas, a distinção entre forma e conteúdo (o que não e consegue por uma qualquer modificação do conhecimento que tematiza, mas precisamente pela viragem da <<tematização>> do discurso). (LÉVINAS, 1988, p. 38)

Expressão também em razão de sua nudez ao apresentarse, que, por sua vez, traz e recebe o olhar, evocando a responsabilidade por este rosto de Outrem.

A linguagem, por sua vez, é o que viabilizaria a própria relação estabelecida entre o Mesmo e o Outro e, mais do que isto, proporcionaria a saída subjetividade de si mesma. Neste sentido, a caracterização da linguagem que se destacaria a Lévinas, não seria a de sua materialidade, mas sim enquanto uma atitude que iria do Mesmo a Outrem.

O discurso, pelo simples facto de manter a distância entre mim e Outrem, a separação radical que impede a reconstituição da totalidade e que é pretendida na transcendência, não pode renunciar ao egoísmo da sua existência; mas o próprio facto de se encontrar num discurso consiste em 
reconhecer a outrem um direito sobre o egoísmo e assim em justificar-se. (LÉVINAS, 1988, p. 27)

A linguagem enquanto discurso se estabelece como exteriorização e, ao mesmo tempo, como revelação de Outrem, uma vez que esta traz em si também o sujeito que a enuncia - por este motivo podemos considerar o discurso, a linguagem oral, a plena realização da linguagem, uma vez que traz em si a estrutura do Rosto do outro também - "Como manifestação de uma razão, a linguagem desperta em mim e em outrem o que nos é comum. Mas ela supõe, em sua intenção de exprimir, nossa alteridade e nossa dualidade." (LÉVINAS, 2004, p. 49).

Assim, a linguagem pressuporia a separação também, no sentido de que

(...) a linguagem fala-se onde falta a comunidade entre os termos da relação, onde falta ou tem apenas de constituir-se o plano comum. Coloca-se nesta transcendência. O Discurso é assim experiência de alguma coisa de absolutamente estranho, <<conhecimento >> ou $<<$ experiência >> pura, traumatismo do espanto. Só o absolutamente estranho nos pode instruir. (LÉVINAS ,1988, p. 60)

Assim, mais do que uma caracterização ontológica da linguagem, que possuiria $o$ papel de exteriorizar e nomear, a 
linguagem teria a função de colocar as coisas em comum - "A linguagem não exterioriza uma representação preexistente em mim põe em comum um mundo até então meu." (LÉVINAS, 1988, p. 155), se estabelecendo nos moldes da relação e proporcionando um vínculo ético.

Linguagem humana instauraria a própria comunidade, mas que só é possível pela absoluta separação entre seus termos.

Por último, a linguagem ainda merece mais uma consideração, qual seja, do modo como esta estrutura um campo em comum, que pressupõe um movimento:

A linguagem é universal porque é a própria passagem do individual ao geral, porque oferece doisas minhas a outrem. Falar é tornar o mundo comum, criar lugares comuns. A linguagem não se refere à generalidade dos conceitos, mas lança as bases de uma possem em comum. Abole a propriedade inalienável da fruição. O mundo no discurso já não é o que é na separação - o <<em minha casa $>>$ em que tudo me é dado -, é aqulo que eu dou, o comunicável, o pensado, o universal. Assim, o discurso não é uma patética confrontação de dois seres que se afastam das coisas e dos outros. (LÉVINAS, 1988, p. 63)

Relação com um cenário da frança contemporânea que faz com que a linguagem adquira uma importância singular em relação aos outros movimentos observados por Blanchot no pensamento de Lévinas. 
A linguagem seria hospitalidade para um Outrem que se apresenta como estrangeiro - tema caro à filosofia francesa contemporânea, inclusive a Blanchot - e sendo este o estatuto do não poder de escapar ao domínio.

Além destas considerações sobre a linguagem realizadas, principalmente em "Totalidade e Infinito", merece nossa atenção ainda a relação estabelecida em "Autrement qu'être ou au-delà de I'essence" que traz a relação entre o dizer e o dito - relação esta que será .

Desde "Totalidade e Infinito" Lévinas começa a apresentar uma cisão entre $o$ modo como a linguagem vinha sendo compreendida, em um contexto ontológico, e entre a proposta levinasiana de uma linguagem ética - que se relaciona com o anteriormente exposto em relação ao Infinito, o Desejo e Rosto.

Tal cisão será apresentada a partir de dois termos: o Dizer e o Dito. Na exposição do filósofo, o Dizer ocupará um lugar privilegiado, em detrimento do Dito.

Anterior aos signos que ele conjuga, anterior aos sistemas linguísticos e aos vislumbres semânticos - introdução das línguas - ele é proximidade de um ao outro, engajamento de aproximação, um pelo outro, a significado da própria significação. ${ }^{73}$.

Ricardo Timm apresenta a seguinte consideração: "O Dizer, "significando antes da essência", é a linguagem do Infinito, e o

73 Livre tradução de: "Antérieur aux signes verbaux qu'il conjue, antérieur aux sysyèmes linguistiques et aux chatoiements sémantiques - avant-propos des langues - Il est proximité de I'un a l'autre, engagement de l'approche, I'un pour I'autre, la signifiance même de la signification" (LÉVINAS, 2006, p. 17). 
falar, a resposta possível à exposição deste Infinito. O Dizer é a realização da lógica do infinito." (SOUZA, 1999, p. 136).

Assim, o Dizer se afirmaria como uma instância ética e comunicativa, em oposição a uma postura ontológica e tematizante ${ }^{74}$ - que seria a adotada pela "filosofia ocidental", e que se relaciona com a estrutura estabelecida a partir da Ética como Filosofia Primeira, pois: "A responsabilidade pelo outro é, precisamente, um Dizer antes de qualquer Dito." (LÉVINAS, 2006, p. 75) ${ }^{75}$.

Ainda neste contexto, o Substantivo deve ser compreendido como a palavra que designa, enquanto o Verbo se insere como duração. Uma vez que a Linguagem como mera designação e tematização não contempla a Linguagem em sua dimensão comunicativa, como Ética, o filosofo adotará a postura relativa à dinâmica do Verbo - e que se relacionaria à estrutura que Blanchot visualiza como constante no pensamento levinasiano - "o par dizer/dito permite a Lévinas visualizar um excesso na linguagem que o dito ontológico não é capaz de esgotar. O excesso do dizer é a própria socialidade da linguagem." (CARRARA, 2012, p. 91).

Estabelecidas as peculiaridades desta estrutura, Lévinas remete ao cenário que anteriormente aqui reconstruímos e que se relaciona, justamente, à questão da existência. A partir disto, Lévinas aponta que o primado da ontologia se faria, de certa forma, quase nos moldes de uma incoerência, uma vez que a Ética, em certa medida, ao analisar a relação, já comportaria a ontologia.

\footnotetext{
74 Neste sentido, trazemos novamente o texto Linguagem e proximidade, o qual relaciona Ontologia e tematização ao considerar que esta "manifesta-se a partir de um tema" (LP, p. 26).

75 Livre tradução de: "La responsabilité pour autrui, c'est précisément um Dire d'avant tout Dit." (LÉVINAS, 2006,p. 75).
} 
A partir destes quatro aspectos apontados por Blanchot podemos considerar uma mesma intenção que pode ser, ao menos em parte, traduzida pela negação à ontologia contemporânea e o primado da ética que é corroborada por diversos desdobramentos. 


\section{Capítulo 04 - A leitura blanchotiana de Lévinas}

A análise proposta neste momento possui duas intenções iniciais diversas, entretanto complementares: primeiro, intenta aprofundar a relação de Maurice Blanchot com a Filosofia e, para tanto, nos aproximarmos ainda mais de Emmanuel Lévinas para, justamente, melhor compreendermos os moldes desta relação.

A interlocução entre os autores notadamente se estabelece de um modo peculiar - menos, talvez, pelos aspectos teóricos que aqui destacaremos e mais pela admiração mútua entre Lévinas e Blanchot, principalmente em razão das considerações que já realizamos a respeito de Blanchot ser demasiadamente reservado e recluso no que poderíamos considerar como a composição de uma cena intelectual da França contemporânea. Antes de entrarmos especificamente na leitura que Blanchot realiza de Lévinas e no impacto que isto proporciona ao seu pensamento, devemos considerar algumas especificidades do pensamento daquele autor, de modo a compreendermos a extensão da relação entre estes pensadores, assim como as implicações de seus pensamentos.

Dentro da extensão da proposta desta tese obviamente cabe realizarmos um recorte sobre o pensamento de Lévinas e, para tal escolha, o faremos prioritariamente a partir da análise realizada por Blanchot no texto "A Literatura e o Direito à Morte" presente na coletânea "A parte do fogo", lançada em 1949, e texto de Blanchot intitulado "Conhecimento do Desconhecido", presente em "Conversa Infinita 1 - A Palavra Plural" , coletânea publicada em 1969, para realizarmos o percurso aqui pretendido. 
A proposta desta orientação remete, imediatamente, à relação entre literatura e filosofia no pensamento de Blanchot, conforme abordamos anteriormente, e, além disto, proporciona uma aproximação a temas centrais do pensamento do autor - e que aqui receberão destaque - de um modo mais precisamente articulado.

Em "A Literatura e o Direito à Morte" Blanchot ocupa-se com temas que mais adiante serão essenciais para 0 desenvolvimento de temas que se fazem presentes no recorte de seu pensamento aqui proposto - a exemplo da morte, da linguagem, da condição da obra literária entre outros.

Para melhor situar o texto, o seu contexto de produção se torna especialmente relevante, uma vez que a situação da literatura encontra-se em pleno debate. Pouco antes da coletânea de Blanchot, em 1947, é lançado na França o ensaio "O que é a literatura?" de Jean-Paul Sartre (1905 - 1980).

A obra sartriana não investigará apenas a literatura e a escrita literária mas sim o escritor e, mais precisamente, o seu engajamento. Assim, a própria condição de escrita estará em pauta: "(...) existe, por trás dos diversos desígnios dos autores, uma escolha mais profunda e mais imediata, que é comum a todos." (SARTRE, 1989 , p. 33). Aprofundar este desígnio, investigar as intenções e o engajamento estruturam a obra de Sartre e estão entorno das seguintes questões: o que é escrever? Por que escrever? Para quem se escreve?.

No mais, há, ainda, claramente uma dimensão política na em "O que é a literatura?" e que contrasta com o precedente de escrita - dos anos 30 e 40 - que aliaria Blanchot à extrema direita francesa. Assim, em meio à discussão a respeito do engajamento do escritor - sendo esta a condição intrínseca à escrita, conforme o posicionamento satreano - é que Blanchot apresentará algumas das 
teses centrais de seu pensamento de modo relativamente estruturado.

Assim, retomaremos o intento a partir de "A Literatura e o Direito à Morte" presente na coletânea "A parte do fogo", lançada em 1949, e texto de Blanchot intitulado "Conhecimento do Desconhecido", presente em "Conversa Infinita 1 - A Palavra Plural" , coletânea publicada em 1969, para realizarmos o percurso aqui pretendido.

Este último texto, que se inicia com a indagação "O que é um filósofo?" (BLANCHOT, 2010, p. 95) dialoga com dois autores muito próximos a Blanchot: Emanuel Lévinas e Georges Bataille este último que também se faz presente como interlocutor em "L'Amitié" em 1971. Blanchot caracteriza o filósofo como alguém que tem medo - mas, destaca-se, um medo qualificado, pois "pelo pavor, saímos de nós mesmo e assim fazemos a experiência assustadora daquilo que é inteiramente fora de nós e radical alteridade: o próprio exterior" (BLANCHOT, 2010, p. 95).

Assim, o desconhecido - tema caro aos debates presentes na França contemporânea - situa o filósofo como um ser angustiado, como aquele que, conhece o desconhecido, que experimenta os limites e, principalmente, o fora deste limite e que traz algumas questões peculiares: "como descobrir o obscuro sem pô-lo a descoberto? Que experiência do obscuro seria esta na qual o obscuro dar-se-ia em sua obscuridade?" (BLANCHOT, 2010, p. 98).

Neste contexto, forma-se um cenário interessante, pois, no momento em que este não-conhecido torna-se conhecido, podemos reduzir o primeiro ao segundo - movimento que quebraria a absoluta alteridade do desconhecido e, de certo modo, perderia o caráter de "desconhecível" - elemento que importa a Blanchot, justamente por sua irredutibilidade. Neste sentido, podemos observar 
um movimento semelhante à argumentação levinasiana em relação ao Mesmo e ao Outrem - o absolutamente outro - que anteriormente abordamos.

Assim, é o medo, mais do que o próprio conhecimento (ainda mais o reconhecimento racional, visto que o medo remete à sensibilidade) que marca o filósofo, a atitude filosófica. É neste sentido que a admiração de Blanchot por Lévinas emerge pois, a partir deste, "é como um novo ponto de partida da filosofia e um salto que ela e nós seríamos convocados a dar" (BLANCHOT, 2010, p. 98).

Com isto, Blanchot destaca e endossa o cerne das considerações de Lévinas a respeito da necessidade da predominância da ética - e não mais da ontologia - como filosofia primeira no cenário contemporâneo:

De uma maneira geral, quase todas as filosofias ocidentais são filosofias do Mesmo e quando elas se preocupam com o Outro, este não passa de um outro eu mesmo, sendo, no melhor dos casos, igual ao eu e procurando ser reconhecido por mim como Eu (assim como eu por ele), numa luta que é por vezes luta violenta, por vezes violência apaziguada no discurso. Mas somos conduzidos pelo ensino de Lévinas em direção a uma experiência radical. (BLANCHOT, 2010, p. 99).

A partir disto, Blanchot observa quatro movimentos diferentes realizados por Lévinas que, de certo modo, expressariam esta relação entre o conhecido e o desconhecido e, principalmente, 
da manutenção desta separação na relação. São eles: a relação entre o finito e o infinito, o Desejo, a relação com o Rosto de Outrem e a linguagem - em especial a linguagem falada, o dizer.

Dentre estes, talvez o mais objetivamente compreensível seja o da relação entre o finito e o infinito, que retoma Descartes: o eu, finito, pensa o infinito e, neste movimento, "o pensamento pensa o que o ultrapassa infinitamente e o que ele não pode dar conta por si próprio: ele pensa então mais do que pensa" (BLANCHOT, 2010, p. 100). Assim, a idéia de desconhecido, de estrangeiro, de alteridade absoluta, de impossibilidade de redução do segundo termo ao primeiro, mas, ainda assim, a manutenção de uma relação entre termos separados - refutando a possibilidade de solipsismo.

Ocorre que, mais do que adentrar às estruturas do pensamento levinasiano, Blanchot tende a considerar $o$ que 0 pensamento de Lévinas representa pois este, possibilitaria, de certo modo - ao considerar a ética e não a ontologia como a filosofia primeira, o fim de uma determinada maneira de se entender o que é a filosofia:

Observemos que ela [a construção do pensamento de Lévinas] poderia levar-nos à denuncia de todos os sistemas dialéticos, e também da ontologia, e inclusive, de quase todas as filosofias ocidentais, daquelas pelo menos que subordinam a justiça à verdade ou não aceitam como justa senão a reciprocidade das relações" (BLANCHOT, 2010, p. 107). 
Ao recriarmos este contexto, no qual Blanchot se envolve com a construção do pensamento filosófico e com os posicionamentos de Lévinas, podemos retomar diversos aspectos da obra deste autor os quais são, inclusive, apontados por Lévinas.

De plano, podemos considerar que a negativa ou afirmação de "Blanchot filósofo", que perfaz uma necessidade de categorização oculta em questões como "o que é um filósofo?", para retomarmos Blanchot, ou "o que é a filosofia?" - e mesmo "o que é a literatura?", para relembrarmos Sartre, passa a receber aqui uma configuração peculiar, visto que a própria filosofia experimentaria, com Lévinas, a experiência de seu fora.

No início de "O olhar do poeta" Lévinas considera que

Blanchot, no entanto, não tende à filosofia: não é questão de ser inferior a tal medida, mas que Blanchot não vê na filosofia uma possibilidade final, nem reconhece, por outros, a possibilidade em si - no "eu posso" - o limite do humano. ${ }^{76}$.

A partir das considerações de Blanchot em "Conhecimento do Desconhecido" a afirmação de Lévinas, de um não pertencimento de Blanchot à filosofia, ganha um aspecto próprio e que guarda relação com o movimento que observamos mas, o que Lévinas faz em relação à ética, Blanchot o faria em relação à arte e, especificamente, com a literatura, pois esta "nos lança, assim, a uma

\footnotetext{
${ }^{76}$ Livre tradução de: "Y sin embargo, Blanchot no tiende a la filosofía. No se trata ya de que su pretenciós sea inferior a una medida tal, sino de que Blanchot no ve en la filosofía la última posibilidad, ni reconoce, por los demás, en la posibilidad misma - en el "yo puedo" - el límite de lo humano." (LÉVINAS, 2000, p. 30).
} 
margem onde nenhum pensamento pode chegar; leva ao impensável." 77

Assim, é iniciado um movimento um tanto quanto semelhante ao que envolve o "Conhecimento do desconhecido", que no contexto literário é reproduzido do seguinte modo: "A essência da arte seria passar da linguagem ao indizível que se diz, para tornar visível através do trabalho a obscuridade do elementar." ${ }^{78}$.

Este movimento, apresentado aqui tanto em relação a Blanchot quanto a Lévinas, retoma o princípio de nosso texto, mobilizando a Filosofia e também, de certo modo, a Literatura, de modo que gostaríamos de aprofundar dois aspectos: retomarmos e ressaltando a maneira como Blanchot lida com a Filosofia e a Literatura para a partir disto, retomarmos a argumentação acima desenvolvida sob o conceito de "fora" trazido por Blanchot.

$\mathrm{Na}$ breve análise que realizamos a respeito dos comentadores de Blanchot, podemos considerar que não há um consenso conceitual do que poderíamos compreender como Filosofia ou como um fazer filosófico. Para cada um dos autores, que brevemente há uma concepção diferente que o relacionaria à Filosofia: ora uma análise de estilo, ora uma análise dos temas propostos por Blanchot ou mesmo dos interlocutores destes - muitas vezes filósofos, como Sartre, Heidegger e o próprio Lévinas.

A este respeito, retomando o contato de Blanchot com a Filosofia, podemos destacar o modo como o autor, em 1971, analisa a linguagem filosófica e, para tal, o faz a partir da perspectiva de

\footnotetext{
77 Livre tradução de: " nos arroja así a una margen donde nigún pensamiento piede arribar; desemboca en lo impensable." ." (LÉVINAS, 2000, p. 38).

78 Livre tradução de: La esencia del arte consistiría en pasar del lenguaje a lo indecible que se dice, en hacer visible por medio de la obra la oscuridad de lo elemental. (LÉVINAS, 2010, p. 38).
} 
Maurice Merleau-Ponty. Nesta oportunidade Blanchot aproxima o escritor e o filósofo e, mais do que isto, destaca algumas características do discurso filosófico

(...) a filosofia é seu discurso, o discurso coerente, historicamente ligado, conceitualmente unificado, formação de sistema e ainda em fase de conclusão ou um discurso, não apenas múltiplo e fragmentado, mas incompleto, marginal, rapsódico, ponderando e dissociado de qualquer direito a ser falado, ainda que por aqueles que se sucederiam, anonimamente, para apoiar e continuar a fazer isso. Esta é, talvez, uma característica que devemos lembrar: o discurso filosófico é primeiramente sem direito. ${ }^{79}$

Frente a este cenário em que a relação de Blanchot com a Filosofia é, a todo momento, colocada à prova podemos considerar o Fora e o Neutro não apenas como uma palavra, mas sim como um termo, um conceito "filosófico" (Cf. MONVALLIER et ROUSSEAU, 2015, p.140).

\footnotetext{
79 Livre tradução de: "(...) la philosophie est son discours, le discours cohérent, historiquement lié, conceptuellement unifié, formant système et toujours en voie d'achèvement ou un discours, non seulement multiple et interrompu, mais lacunaire, marginal, rhapsodique, ressassant et dissocié de tout droit à être parlé, fût ce par ceux qui se succéderaient, anonymement, pour le soutenir et le poursuivre en le rendant présent. Voilà peutêtre un trait qu'il nous faut retenir: le discours philosophique est d'abord sans droit." (BLANCHOT, 2010.2, p. 2).
} 
De um modo mais objetivo, devemos retomar a explicação de Peter Pál Pelbart de modo a auxiliar a compreensão do "fora":

O que é uma força? É relação com outra força. Uma força não tem realidade em si, sua realidade íntima é sua diferença em relação às demais forças, que constituem seu exterior. Cada força se "define" pela distância que a separa das outras forças, a tal ponto que qualquer força só poderá ser pensada no contexto de uma pluralidade de forças. O Fora é essa pluralidade de forças. O Fora, que é o exterior da força, é também sua intimidade, pois é aquilo pelo que ela existe e se define. O Fora não é a plenitude de um vazio onde viriam alojar-se as diferentes forças previamente constituídas. O Fora é a distância entre as forças, isto é, a Diferença. (PELBART, 1989, p. 121)

Em um outro momento do texto, o autor analisa novamente o conceito de "fora", mas agora relacionando-o a Lévinas:

A questão do Outro em Blanchot segue a trilha aberta por Emmanuel Levinas, que em sua ética "fundamental" substituiu, ao primado da ontologia, o da relação de alteridade. Entretanto, ao assimilar o Outro ao Fora, (...) Blanchot utiliza essa ética como uma estratégia de des-subjetivação (...), isto 
é, de abertura para o Fora. (PELBART, 1989, p. 99).

Assim, podemos considerar que a relação de Blanchot com a Filosofia se estabelece pelo seu "fora". Talvez por este motivo a dificuldade de seus comentadores em defini-lo como um filósofo seja tão recorrente. A "filosofia" na qual ele se situaria, não é mais a que compreendemos em sua construção histórica no ocidente, pautada pela ontologia e pelo mesmo, mas sim uma nova filosofia (ou mesmo a morte da filosofia) - trazida, principalmente, por Lévinas.

Em certa medida, podemos considerar que a relação de Blanchot com a Filosofia e de Blanchot com Lévinas se confundem e trazem aspectos por meio de seus comentadores como:

a contribuição de Levinas cujo pensamento, da Totalidade e do Infinito, é assimilado por Blanchot ao movimento do pensamento filosófico: um movimento que ele define como o de "submeter [o] filosófico a um questionamento tão radical que é preciso toda a filosofia para apoiá-lo." 80

\footnotetext{
80 Livre tradução de: "I'apport de Levinas dont la pensée, À partir de Totalité et infini, est assimilée par Blanchot au mouvement de la pensée philosophique tout court: mouvement qu'il définitcomme celui de <<soumett[re] le philosophique [...] à une mise en question si radicale qu-il faut toute la philosophie pous la soutenir. >> " (NORDHOLT, 2007, p. 96)
} 


\section{Considerações Finais}

A título de considerações finais intentamos, ainda retomar os aspectos principais do pensamento de Blanchot, principalmente no remete ao pensamento à nossa proposta de recorte - no que inicialmente se refere à Lévinas, a exemplo do Fora e do Neutro, mas que também tangencia questões como a Subjetividade, a Morte, entre outros.

No mais, cabe abordarmos também considerar que, ao abordarmos a figura de Blanchot pela sua ausência, consideramos ser importante considerarmos as relações entre Blanchot e Levinas a partir não apenas de suas semelhanças e aproximações, mas talvez, em razão da própria estrutura de seus pensamentos, também seja relevante pensar suas diferenças.

Em relação a isto, cabe apontarmos, principalmente, as relações entre as concepções de Neutro e Outro que, para seus comentadores, acaba por distanciar Blanchot e Lévinas ( GARAMONT, 2011, p. 115), de modo a explorar que, "Blanchot e Levinas podem pensar o mesmo, ams é justo dizer que eles interpretam de forma bastante diferente." ${ }^{81}$.

Assim, para encerrarmos e articularmos o pensamento estabelecido entre literatura e filosofia, assim como da articulação do pensamento de Blanchot e de Lévinas, desejaríamos abordar ainda mais um ponto, entorno do conceito de comunidade. A partir de tal conceito, estruturaríamos que este representa não apenas a própria

\footnotetext{
${ }^{81}$ Livre tradução de: "Dès lors, Blanchot et Levinas peuvent bien penser le même, il est juste de dire qu'ils l'interprètent tout autrement." (GARAMONT, 2011, p. 114)
} 
relação entre filosofia e literatura, mas também um aspecto capaz de estruturar profundamente seu pensamento.

Além disto, é possível analisar que, em certa medida, o conceito de comunidade de Blanchot é estruturado a partir da afetação de Lévinas - e das temáticas compartilhadas por este com o pensamento de Blanchot. 


\section{Bibliografia}

ARISTÓTELES. Ética a Nicômaco; Poética. Seleção de textos de José Amério Morra Pessanha. São Paulo: Nova Cultura, 1987. (Os Pensadores)

BADIOU, Alain. A aventura da filosofia francesa no século XX. Trad. Antônio Teixeira, Gilson Iannini. 1 ed. Belo Horizonte: Autêntica Editora, 2015.

BATAILLE. Georges. A experiência interior: seguida de Método de Meditação e Postscriptu, 1953: Suma ateológica, vol I. Trad e apresentação Fernando Scheibe. Belo Horizonte: Autêntica Editora, 2016.

- O culpado: Seguido de A aleluia.

Suma ateológica, vol. II. Trad e apresentação Fernando Scheibe. Belo Horizonte: Autêntica Editora, 2017.

.Teoria da Religião: seguida de Esquema de uma história das religiões. Trad Fernando Scheibe. Belo Horizonte: Autêntica Editora, 2016.

BEAUFRET, Jean. Introdução às filosofias da existência: de Kierkegaard a Heidegger. Trad. e notas Salma Tannus Muchail. São Paulo: Duas Cidades, 1976.

BIDENT, Christophe. De la chronique à la théorisation. In Blanchot dans son siècle. Associations des amis de Maurice Blanchot. Lyon: Sens Public - Editions Parangon, 2009.

Maurice Blanchot: partenaire invisible - essai biographique. Seyssel: Éditions Champ Vallon, 1998. 
BLANCHOT, Maurice. A conversa infinita. Tradução: Aurélio Guerra Neto. São Paulo: Escuta, 2010. Vol. 1. A Palavra grafgraphique.

A parte do fogo. Trad. Ana Maria Scherer. Rio de Janeiro: Rocco, 2011.

- A comunidade inconfessável. Trad. de Eclair Antônio Almeida Filho. Brasília: Editora Universidade de Brasília; São Paulo: Lumme Editor, 2013.

- A conversa infinita 1: a palavra plural (palavra de escrita) Trad. Aurélio Guerra Neto. São Paulo: Escuta, 2010.

A conversa infinita 2: a experiência limite. Trad. João Moura Jr.. São Paulo: Escuta, 2007.

. Chroniques politiques des années trente (1931 - 1940). Paris: Éditions Galllimard, 2017. . Écrits politiques 1953-1991.

Paris: Éditions Gallimard, 2008. - L'Écriture du désastre. Paris: Éditions Gallimard, 1914. . Le « discours philosophique » In: Maurice Blanchot et la philosophie: Suivi de trois articles de Maurice Blanchot [en ligne]. Nanterre: Presses universitaires de Paris Ouest, 2010.2. Disponível em: http://books.openedition.org/pupo/1133. ISBN : 9782821826878. . Lettres à Vadim Kozovoï. Édition étable, presentée et annotée par Denis Aucouturier suivi de La parole Ascendane ou Sommes-nous encore dignes de la poésie? (notes éparses). Houilles: Éditions Manucius, 2009. 
L'espace littéraire. Paris:

Éditions Gallimard, 1955.

. Le pas 1u-delá. Paris: Gallimard,

1973.

. Notre compagne clandestine In :

Maurice Blanchot et la philosophie : Suivi de trois articles de Maurice Blanchot [en ligne]. Nanterre : Presses universitaires de Paris Nanterre, 2010 (généré le 08 septembre 2019). Disponible sur Internet : <http://books.openedition.org/pupo/1137>. ISBN : 9782821826878. DOI : 10.4000/books.pupo.1137.

- O livro por vir. Trad. Leyla

Perrone-Moisés. 2a ed.. São Paulo: WMF Martins Fontes, 2013.

. O passo além. Trad. Daniel

Barbosa Cardoso e Eclair Antonio Almeida Filho. São Paulo: Lumme Editor, 2016.

- Récits Critiques. Textes réunis par Christophe Biden et Pierre Vilar. France: Éditions Farrado et Éditions Léo Scheer, 2003.

. Une voix venue d'ailleurs. Paris:

Éditions Gallimard, 2002.

. Uma voz vinda de outro lugar.

Trad. Adriana Lisboa. Rio de Janeiro: Rocco, 2011.

BRUNS, Gerald. Maurice Blanchot - the refusal of philosophy. London: The Johns Hopkins University Press, 2005.

BUCLIN, Hadrien. Maurice Blanchot ou L'autonomie Littéraire. Suisse: Éditions Antipodes, 2011.

CARRARA, Ozanan Vicente. Linguagem e Socialidade em Emmanuel Levinas. In Síntese: Revista de Filosofia. Departamento de 
filosofia, Faculdade Jesuíta de Filosofia e Teologia. V. 39, n. 123. Belo Horizonte: FAJE, 2012.

CHOPLIN, Hugues. L'enfance de la philosophie - à partir des déconstructions. In Revue Métaphysique et de Morale. Avril-jui 2015 n02 - Blanchot: Écriture et philosophie. Paris: Presses Universitaires de France, 2015.

COHEN-LEVINAS. Danielle. Entre eux Maurice Blanchot et Emmanuel Levinas... Là où ils sont, se rendre à l'impossible. In Blanchot dans son siècle. Associations des amis de Maurice Blanchot. Lyon: Sens Public - Editions Parangon, 2009.

COLLIN, Françoise. Maurice Blanchot et la question de l'écriture. Paris: Gallimard, 1986.

COOLS, A. Langage et subjectivité. Vers une approche du différend entre Maurice Blanchot et Emmanuel Lévinas. Leuven: 2007.

COSSUTTA, Frédéric, «Discours philosophique, discours littéraire : le même et l'autre ? », Rue Descartes, 2005/4 ( $n^{\circ} 50$ ), p. 6-20. URL: https://www.cairn.info/revue-rue-descartes-2005-4-page6.htm

DERRIDA, Jacques. Adeus a Emmanuel Lévinas. Trad. Fábio Landa com a colaboração de Eva Landa. São Paulo: Perspectiva, 2008.(Debates; 296).

DUGNOILLE, Julien. Le désir d'anonymat - chez Blanchot, Nietzsche et Rilke. France: L'Harmattan, 2004.

FAGES, J. B. Comprendre Roland Barthes. Toulouse: Edouard Privat, 1979.

FRIES, Philippe. La théorie fictive de Maurice Blanchot. Paris: L'Harmattan, 1999.

GRAMONT, Jérôme de. Blanchot et la phánoménologie L'effacement, l'événement. France: Éditions de Corlevour, 2012. 
GREGG, John. Maurice Blanchot and the literature of transgression. New Jersey: Princeton University Press, 1994.

HADDOCK-LOBO, Rafael. Da existência ao Infinito: ensaios sobre Emmanuel Lévinas. São Paulo: Loyola, 2006.

HAMEL. Jean-François. Nous sommes tous la pègre - les années 68 de Blanchot. Canada: Les éditions de Minuit, 2018.

HARLINGUE, Oliver. Sans condition. Blanchot, la littérature, la philosophie. Paris: L'Harmattan, 2009.

HART, Kevin. <<Le troisième rapport>>. In Blanchot dans son siècle. Associations des amis de Maurice Blanchot. Lyon: Sens Public - Editions Parangon, 2009.

HEWSON, Mark. Blanchot and literary criticism. New York: Continuum, 2011.

HILL, Leslie. Blanchot. Blanchot extreme contemporary. New York: Routledge, 2001.

HILL, Leslie. Le tournant du fragmentaire. In Revue littéraire mensuelle Maurice Blanchot, Antoine Volondine. $85^{\circ}$ année. no 940-941- août-Septembre 2007. Paris.

HOPPENOT, Éric. Avant-propos. In Revue Métaphysique et de Morale. Avril-jui 2015 n² - Blanchot: Écriture et philosophie. Paris: Presses Universitaires de France, 2015.

- Blanchot et l'écriture fragmentaire. In

L'Épreuve du temps chez Maurice Blanchot - Collection Compagnie de Maurice Blanchot. Paris: Les Éditions Complicités, 2006.

HOPPENOT, Éric et MILON, Alain (direction). Maurice Blanchot et la philosophie - suivi de trois articles de Maurice Blanchot. France: Press Universitaires de Paris Ouest, 2010.

HURAULT, Marie-Laure. Maurice Blanchot - Le principe de fiction. Saint-Denis: Presses Universitaires de Vincennes, 1999.

HUTCHENS, B. C. Compreender Lévinas. Tradução Vera Lúcia Mello Joscelyne. Petrópolis: Vozes, 2007. 
KALINOWSKI, Isabelle. «La littérature dans le champ philosophique français de la première moitié du XXe siècle », Methodos [En ligne], 1 | 2001, mis en ligne le 05 avril 2004. URL : http://journals.openedition.org/methodos/53.

LÉVINAS, Emmanuel. Autrement qu'être ou au-delá de l'essence. 5 ed. Barcelone: Liberdúplex, 2006.

- Descobrindo a existência com

Husserl e Heidegger. Trad. Fernanda Oliveira. Lisboa: Instituto Piaget, 1997.

- Entre nós: ensaios sobre a

alteridade. Trad Pergentino Stefano Pivatto (coord.) e José Nedel

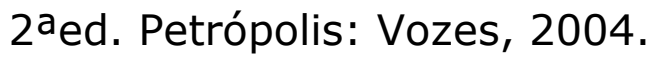

. Éthique et infini - dialogues avec

Philippe Nemo. Paris: LGF, 2008.

- Humanismo do outro homem.

Trad. Pergentino S. Pivatto (coord.). Petrópolis, RJ: Vozes, 1993.

. Sobre Maurice Blanchot. Edición de

José M. Cuesta Abad. Madrid: Editorial Trotta, 2000.

Sur Maurice Blanchot. Paris: Fata

Morgana, 1975.

. Totalidade e Infinito Tradução José

Pinto Ribeiro. Lisboa, Portugal: Edições 70, 1988.

LÉVY, BENNY. Être juif - Étude lévinassienne. Lagrasse:

Éditions Verdier, 2003.

LEVY, Tatiana Salem. A experiência do fora: Blanchot, Foucault e Deleuz. Rio de Janeiro: Civilização Brasileira, 2011.

LIMET, Maurice Blanchot Critique. Paris: La Différence, 2010. 
MACLACHLAN, Ian. Lire, écrire: Blanchot et Laporte. In Blanchot dans son siècle. Associations des amis de Maurice Blanchot. Lyon: Sens Public - Editions Parangon, 2009.

MARTY, Éric. Maurice Blanchot, Roland Barthes, une $<$ <ancienne conversation>>. Paris: Gallimard - Les Temps modernes, 2009/3 (n0654), p. 74-89. (Disponível em: https://www.cairn.info/revue-les-temps-modernes-2009-3-page74.htm).

MELO, Nelio Vieira de A Ética da Alteridade em Emmanuel Lévinas. Porto Alegre: EDIPUCRS, 2003.

MERLEAU-PONTY, Maurice (direction). Les philosophes de l'Antiquité au XXe siècle : histoire et portraits. Paris: La Pochothèque, 2006.

MILON, Alain. Entre Blanchot et la philosophie In : Maurice Blanchot et la philosophie: Suivi de trois articles de Maurice Blanchot. Nanterre: Presses universitaires de Paris Ouest, 2010. Disponível em: http://books.openedition.org/pupo/1098>. ISBN : 9782821826878. DOI : 10.4000/books.pupo.1098.

MIRAUX, Jean-Philippe. Maurice Blanchot - Quiétude et inquiétude de la littérature. Paris: Éditions Nathan, 1998.

MONVALLIER, Henri et ROUSSEAU, Nicolas Blanchot L'obscur ou La Déraison Litteraire. Paris: Éditions Autrement, 2015.

MORA, Frédéric. L'impossibilité d'une île. In Blanchot dans son siècle. Associations des amis de Maurice Blanchot. Lyon: Sens Public - Editions Parangon, 2009.

NANCY, Jean-Luc. A comunidade inoperada. Trad. Soraya Guimarães Hoepfner. 1 e. Rio de Janeiro: 7 letras, 2016. 
NORDHOLT, Annelise Schulte. Le $<<$ vrai bilinguisme $>>$ Théorie e pratique. In Revue littéraire mensuelle Maurice Blanchot, Antoine Volodine. $85^{\circ}$ année. no 940-941- août-Septembre 2007. Paris.

PELBART, Peter Pál. Da clausura do fora ao fora da clausura - loucura e resrazão. São Paulo: Editora Brasiliense, 1989.

PINAT, Etienne. Les deux morts de Maurice Blanchot. Une phénoménologie. Préface par Jérôme de Gramont. Romania: Zeta books, 2014.

PLATÃO. A república: [ou sobre a justiça, diálogo político] Trad. Anna Lia Amaral de Almeida Prado; Rev. técnica e intro. Roberto Bolzani Filho. São Paulo: Martins Fontes, 2006.

POIRIÉ, François. Emmanuel Lévinas: ensaio e entrevista. Trad. J. Guinsburg, Márcio Honorio de Godoy e Thiago Blumenthal. São Paulo: Perspectiva, 2007. (Debates; 309)

PONZIO, Augusto. Sujet et altérité sur Emmanuel Lévinas - suivi de Deux dialogues avec Emmanuel Lévinas. Traduit de l'italien par Nicolas Bonnet. Paris: Éditions L'Harmattan, 1996.

QUEIROZ, André; MORAES, Fabiana de; CRUZ, Nina Velasco e (org.s). Barthes/Blanchot: um encontro Possível?. Rio de Janeiro: 7letras, 2007.

QUEIROZ, André; ALVIM, Luiza; OLIVEIRA, Nilson. Apenas Blanchot!. Rio de Janeiro: Pazulin Ed., 2008.

RAVEL, Emmanuelle. Maurice Blanchot et l'art au XXéme siècle - une esthétique du désoeuvrement. Amsterdam, New York: Chiasma 24, 2007.

REGNIER, Thomas. La question du nihilisme. In Revue littéraire mensuelle Maurice Blanchot, Antoine Volodine. $85^{\circ}$ année. no 940-941- août-Septembre 2007. Paris. 
RICOEUR, Paul. Outramente: Leitura do livro Autrement quêtre ou au-delà de l'essence de Emmanuel Lévinas. Trad. Pergentino Stefano Pivatto. Petrópolis, RJ: Vozes, 1999.

SANTI, Sylvain. Écrire à l'ami. In Revue littéraire mensuelle Maurice Blanchot, Antoine Volodine. $85^{\circ}$ année. no 940941- août-Septembre 2007. Paris.

SAMARSKY, Christophe. Le pas au-delà de Maurice Blanchot - Écriture et éternel retour. Paris: L'Harmattan, 2011.

SARTRE, Jean-Paul. O que é a literatura? Trad. Carlos Felipe Moisés. São Paulo: Editora Ática, 1989.

SOUZA, Ricardo Timm de. Sujeito, ética e história: Lévinas e o traumatismo infinito e a crítica da filosofia ocidental. Porto Alegra: EDIPICRS, 1999.

SURYA, Michel. L'autr Blanchot. L'écriture de jour, l'écriture de nuit. Paris: Gallimard, 2015.

WYSCHOGROD, Edith. "Language and alterity in the thought os Levinas. In The Cambridge Companion to Levinas. Edi. Simon Critchley and Robert Bernasconi. Cambridge: Cambridge University Press, 2004. 